\title{
The effect of density, initial moisture content, and spontaneous heating on drying isotherms of alfalfa
}

\author{
C. A. Cromer \\ E. B. Collins \\ W. R. Guthrie
}

Follow this and additional works at: https://researchrepository.wvu.edu/ wv_agricultural_and_forestry_experiment_station_bulletins

\section{Digital Commons Citation}

Cromer, C. A.; Collins, E. B.; and Guthrie, W. R., "The effect of density, initial moisture content, and spontaneous heating on drying isotherms of alfalfa" (1966). West Virginia Agricultural and Forestry Experiment Station Bulletins. 531T.

https://researchrepository.wvu.edu/wv_agricultural_and_forestry_experiment_station_bulletins/667 
West Virginia University Libraries 
Digitized by the Internet Archive in 2010 with funding from Lyrasis Members and Sloan Foundation 


\section{THE EFFECT OF DENSITY, \\ INITIAL MOISTURE CONTENT, AND SPONTANEOUS HEATING \\ ON DRYING ISOTHERMS OF ALFALFA}

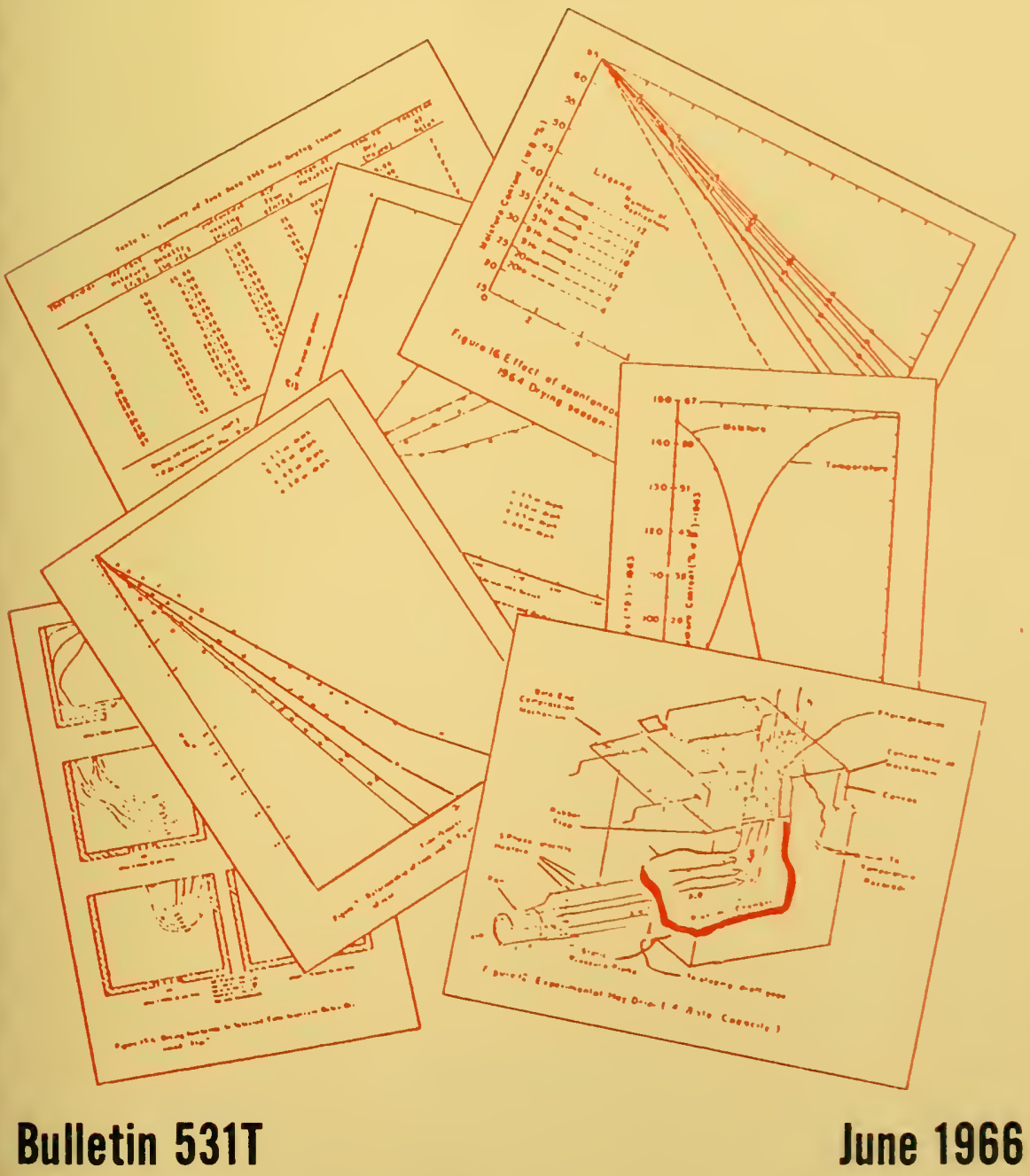




\section{THE AUTHORS}

C. A. Cromer and W. R. Guthrie are former Graduate Research Assistants, and E. B. Collins, former Assistant Agricultural Engineer.

West Virginia University Agricultural Experiment Station College of Agriculture and Forestry

A. H. VanLandingham, Director 


\section{THE EFFECT OF DENSITY, \\ INITIAL MOISTURE CONTENT, \\ AND SPONTANEOUS HEATING \\ ON DRYING ISOTHERMS OF ALFALFA}

\section{A. Cromer, E. B. Collins, and W.R. Guthrie}

The phenomenon of spontaneous heating has long been observed and associated with storage or large quantities of moist grasses. If this heating is allowed to proceed unchecked, spontaneous ignition, or combustion. often results.

Respiration of the plant plays an integral part in the early stages of spontaneous heating. The end products of this respiration are heat, carbon dioxide, and metabolic water. The warm moist atmosphere produced is an excellent environment for the development and activity of microorganisms and enzymes.

Many of the biological aspects involved are not completely understood, despite a number of extensive investigations. So far, progress has been mainly in the direction of recognition of the factors involved, but the relative importance and interaction of the various agencies involved are not fully understood. The method used for investigation may often predetermine the results. The evolution of heat is the process under investigation, but it must be recognized that the temperature of the heating mass will often determine the further course of the phenomenon.

Browne (1), Henson (5), James (8), Hoffman (6), and Rochbaum (11) have made available an interesting and extensive review of observations and theories of spontaneous heating. Most of the researchers will agree that microorganisms are present in the early stages of the evolution of heat in damp hay. The fungi are considered only of importance when the heating occurs slowly (5). Bacteria are probably present in the entire range from air temperature to $70^{\circ} \mathrm{C}$. Respiration of the living cells of the plant also enter into the heating process $(2,4,5,14)$. Chemical oxidations probably play an important part when the temperature rises to at least $70^{\circ} \mathrm{C}(8)$. 
Spontaneous heating was shown by Phillips (10) to bring about the formation of moist spots near the top of alfalfabales which were extremely difficult to dry in commercial systems. For this reason, the effect of spontaneous heating had to be considered when evaluating factors which affect the drying process. Methods for determining moisture content of bales by conventional means were difficult because drying temperatures of $130^{\circ} \mathrm{F}$ and $160^{\circ} \mathrm{F}$ were used in the tests. These high temperatures made the use of resistance and capacitance moisture meters extremely unreliable. A method for determining moisture content was desired in which temperature would not affect reliability.

In any system which uses air as the medium to remove moisture from the product, the temperature of the air will decrease due to the heat used in evaporating moisture. Jennings (9) stated that the temperature drop of drying air varies with the moisture content of the hay and the humidity of the drying air as it enters the product. Phillips (10) found that the depth of the drying zone along any vertical line in the bale was usually within a range of two inches. If constant air flow of a uniform condition is used during the entire drying process, then the decrease in moisture content in each zone will be indicated by the temperature drop.

An isotherm* will be defined as a line which connects points of equal temperature.

\section{INVESTIGATION}

Tests and small samples

Tests were conducted on small samples to determine the relationship between temperature and moisture content. Four small samples were placed in series in the same air stream. (Typical moisture curves are presented in Figure 1 and the corresponding temperature curves are given in Figure 2.)

As air passed through each sample in order, from 1 to 4 , a drop in sample temperature occurred. The temperature curves lag one another in the reverse order in which air passed through the samples. The moisture curves exhibit the same lag. Drying in each small sample was nearing completion before any appreciable moisture loss occurred in the next sample through which air passed. This indicates that drying occurs in a relatively thin layer of hay before progressing toward the point where the air is exhausted. It was observed from plots of this data versus time that the average temperature-time curve for a drying sample was approxi-

\footnotetext{
* Isotherm is the name commonly applied to an equilibrium moisture curve corresponding to a specific temperature (3).
} 
mately the inverse of the average moisture content-time curve, provided that the plotting scale was adjusted so that the beginning moisture content coincided with the final temperature (Figure 3). Thus, there exists a straight line relationship between moisture-content and temperature at a given time (Figure 4). The equation relating average temperature with average moisture content is:

$$
T-T_{1}=\left(M-M_{1}\right) \frac{\left(T_{2}-T_{1}\right)}{\left(M_{2}-M_{1}\right)}=b\left(M-M_{1}\right)
$$

where:

$\mathrm{T}=$ average temperature at a given time

$\mathrm{M}$ = average moisture content at a given time

$\mathrm{T}_{1}=$ average initial temperature

$\mathrm{T}_{2}=$ average final temperature

$\mathrm{M}_{1}=$ average initial moisture content

$M_{2}=$ average final moisture content

$b=$ slope of temperature-moisture content line or solving for the moisture content at a given time:

$$
M=\frac{\left(T-T_{1}\right)}{b}+M_{1}
$$

The slope $b$ represents the average moisture content at a given time from the average temperature throughout the sample. This could be accomplished without disturbing the sample. If a representative moisture content sample can be obtained at the beginning and the end of drying, the slope may be calculated using the two-point slope equation:

$$
b-\frac{T_{2}-T_{1}}{M_{2}-M_{1}}
$$

The accuracy of this analysis depends upon the "representativeness" of the averages used in the calculation. It was applied to several sets of drying data and has been found to give good results (Figure 5). Predictions were very good with bale size samples weighing approximately 50 pounds. Thus, a line connecting points of equal temperature (isotherms) should also be lines of constant moisture content in a given sample. Examples of the isotherms for baled alfalfa hay, are shown in the Appendix.

\section{Samples of different depths}

A useful equation of simple form can be derived for the falling-rate period by assuming that the rare of drying during the falling-rate period is directly proportional to the free-water content. This assumption is only a rough approximation (12). The rate of drying is zero ar the equilib- 
rium moisture content and equal to the constant rate at the critical morsture. Sherwood (12) developed Equation 4.

$$
\log E^{\prime}=-\kappa \theta^{\prime}
$$

where: $\theta^{\prime}=$ the time elapsed since reaching the critical moisture content

$\mathrm{E}^{\prime}=$ the moisture content ratio

$\kappa=$ a drying constant

The $E^{\prime}$ of Equation 4 is the ratio of the free-water content at any time $\theta^{\prime}$ to the free-water content at the beginning of the drying or following the critical moisture content. It has been shown that a semi-log plot of $E^{\prime}$ versus $\theta^{\prime}$ will result in a straight line. Since the equilibrium moisture content of the samples used in the tests was quite small, a plot of $W / W_{0}$ will result in a straight line when plotted on semi-log paper. $W_{0}$ is the moisture content at some beginning point and $W$ is the moisture content at some later time. This relationship was determined for samples of different depths. An example of the resulting curves is presented in Figure 6 . The resulting curvature in the initial portion of the curves is probably a result of the heating period. The 1.5 -inch sample did not exhibit this heating period, indicating that thin layer drying* occurred, the resulting curve for it being a straight line. The remaining three curves are also straight lines following this initial period of heating. The entire period of drying probably takes place in the falling-rate period, with bound water causing the break in the lower portion of the plots.

It was desirable to eliminate the heating portion of the curves so that a drying constant for samples of different depths could be computed. This may be accomplished by selecting a value of $W_{0}$ equal to approximately 0.6 the moisture at the time drying was started. The resulting curve is shown in Figure 7 . This is the same data used for Figure 6.

The drying rate for small samples of various depths was determined by graphical differentiation. Figure 8 shows drying rate versus moisture content, and Figure 9 shows variation of drying rate with time. It will be noted from Figure 8 that the drying rate for the different depths of hay coincide below 20 per cent moisture. This indicates that the drying rate in this range is independent of depth of hay.

\section{Heating in static bales}

Alfalfa hay baled at moisture contents above 30 per cent (W. B.) began spontaneous heating almost immediately after baling unless air was forced through the bale. The heating in a single.bale produced a maximum temperature ranging from $120^{\circ} \mathrm{F}$ to $140^{\circ} \mathrm{F}$. This temperature

* Thin layer drying refers to the drying of a solid which is entirely exposed to air of a constant condition moving through the product (3). 
was reached within a period of six to ten hours after baling. A gradual fall in temperature followed.

For the first eight hours after baling, the temperature rise may be represented by the equation:

$$
\mathrm{Y}=4.6 \mathrm{X}+\mathrm{C}
$$

where:

$$
\begin{aligned}
& \mathrm{X}=\text { the time after baling (hours) } \\
& \mathrm{Y}=\text { the temperature }\left({ }^{\circ} \mathrm{F}\right) \\
& \mathrm{C}=\text { initial temperature of the bale }
\end{aligned}
$$

A scatter diagram of recorded temperatures during the spontaneous heating period is shown in Figure 10. Moisture content during the heating process remained nearly constant. The greatest variation encountered was a rise of about five per cent (W. B.) in bale moisture content.

\section{Bale drying equipment used}

A two-bale experimental drier was constructed (Figure 11) for the 1963 hay-drying season. The top of the chamber was omitted to enable bales to be easily inserted in the drier chamber and also to permit the thermocouples to be readily inserted in the bale. A Chromalox electronic thermostat was used to control the temperature of the drying air. With the system shown in Figure 9, the temperature of the drying air could be controlled to $\pm 4^{\circ} \mathrm{F}$. Compression on the bales was maintained by the use of two screw-type mechanisms which were adjusted to maintain a constant static pressure during the entire drying period. A four-inch opening in the bottom of the chamber permitted air to pass from the plenum chamber up through the hay.

All the tests conducted during this season were with the bales oriented "flat" except for three tests which consisted of one bale "flat" and one "on edge." These tests were used for direct comparison of the bale orientation. Drying temperature was maintained at $160^{\circ} \mathrm{F}$.

The research during the 1964 season used bales oriented "on edge" with the drying temperature maintained at $130^{\circ} \mathrm{F} \pm 2^{\circ} \mathrm{F}$. The experimental drier was re-designed to handle four bales in each test (Figure 12).

\section{Test procedure}

Bales were placed in the drier, and thermocouples were inserted at the points shown by the grid system in Figure 13. Compression was applied by means of the screw-type mechanism until the sides of the chambers fitted securely against the bales. The static pressure was then measured with a sloping draft gage. This static pressure was maintained throughout the test. A 48-point Brown potentiometer was used to indicate temperature. A drying temperature of $160^{\circ} \mathrm{F}$ was used for all tests conducted during the 1963 season, and temperature of $130^{\circ} \mathrm{F}$ was used for all 
tests conducted during the 1964 season. After allowing spontaneous heating to occur for a selected period of time, air flow was started. An Alnor velometer was used to determine air flow. The velometer had been calibrated against a flow tube.

\section{ANALYSIS}

Variables involved

The independent variables involved in the tests conducted were:

1. Bale density

2. Moisture content

3. Time of spontaneous heating prior to the start of air flow.

Temperatures within the bales

Isotherms for selected time intervals are presented in Appendix C. Temperatures plotted for different points located one above the other on a vertical line through the center of the bale are shown in Figure 14 and 15. The letters on the curves correspond to the points shown as letters in the grid system of Figure 13. These bales were secured from the same field, at the same time, and differed only in bale density. After the same period of spontaneous heating, they were placed in the drier, one "flat" and one "on edge." The bale "on edge" was found to dry much faster than the bale "flat."

An abrupt drop in temperature, due to the presence of metabolic water liberated by the respiring plants while undergoing spontaneous heating, will be noted for all points in the bales when air flow was initiated. The moisture is on the surface of the plants where it is readily available for evaporation, which results in evaporation occurring at its maximum rate with the wet bulb temperature of the air being approached by the drying air. Following the removal of the "free" water from the bale, the temperature of the bale began to increase. This temperature increase occurred by layers as the drying progressed upward through the bale. Drying first began near the edge of the bales. As the point of measurement was further displaced from the point where the drying air entered, the corresponding temperature curves for this point lagged those of any point lower in the bale. This same lag was also exhibited by the small samples. A summary of all tests is presented in Tables 1 and 2.

Following the initial period, the temperature curves of Figures 14 and 15 are nearly straight lines until the temperature of the drying air is approached. The straight line portions are nearly parallel in this range, indicating that there is a relationship between the moisture content and the temperature of the product. Figure 16 represents the drying curves of all tests conducted during the 1964 season. The spontaneous heating 
periods ranged from 1 to 20 hours. These graphical represcntations indicate that spontaneous heating over long periods accelerates the time of drying; however, those intervals in excess of 8 hours produce an unacceptable product for animal consumption. Short periods of spontancous heating increased the drying time.

\section{Application of Hukill's analys is}

The analys is of drying developed by Hukill (7) was used to compute the drying time. A sample calculation using this method is presented in Appendix A. The calculated results for all tests are presented in Tables 3 and 4. Drying time determined by using isotherms is prescented for comparison.

\section{Effect of the different variables}

Using the method of least squares (Appendix B) a multiple regression equation for drying time was developed. The three variables involved are: (a) bale density, (b) moisture content, and (c) time of spontaneous heating. These equations are valid only for the range of conditions at which the tests were conducted.

Equation 6 represents the regression equation for bales oriented "flat" with a drying temperature of $160^{\circ} \mathrm{F}$, and Equation 7 for bales oriented "on edge" with a drying temperature of $130^{\circ} \mathrm{F}$ :

$$
\begin{aligned}
& Y_{f}=-18.66+2.74 X_{1}-0.43 X_{2}+0.175 X_{3} \\
& Y_{e}=-16.57+1.52 X_{1}+0.75 X_{2}+.26 X_{3}
\end{aligned}
$$

where:

$$
\mathrm{Y}=\text { drying time (hours) }
$$

$\mathrm{X}_{1}=$ bale density $(\mathrm{dry})\left(\mathrm{lbs} / \mathrm{ft}^{3}\right)$

$\mathrm{x}_{2}=$ spontaneous heating period (hours)

$\mathrm{X}_{3}=$ initial moisture content $\mathbb{W}$. B. (per cent)

Multiple correlation coefficient for Equation 6 was (0.92), and for Equation 7, (0.87).

Spontaneous heating effects on the drying time differed with bale orientation. Bales or iented "flat" exhibited a negative correlation, while bales oriented "on edge" exhibited a positive correlation.

The variable exhibiting the greatest influence on drying time was bale density in both systems of orientation.

The second greatest effect was spontaneous heating with bales riented "flat" and initial moisture content with bales oriented "on edge." The drying constant

From plots of $\mathbb{W}^{\prime} / \mathbb{W}_{0}$, such as shown in Figure 7 , values of $\kappa$ for Equation 4 were determined. The value of $\kappa$ is the slope of the semi-lot plot (Figure 7). Figure 17 indicates the effect that different depths of 
hay for the samples have upon the drying constant. The constant applies to the following rate period of drying and should not be considered representative of the lowerportions of the curves (for values of $\mathbb{W} / \mathbb{W}_{0}$ less than 0.02 ). A different mechanism, probably that of bound water, is controlling the drying rate at these moisture contents. This is indicated by the breaks in the curves.

\section{CONCLUSIONS}

The variables investigated (dry density, initial moisture content, and spontaneous heating) all exhibited a definite effect upon the drying rate of alfalfa.

Dry density was the most prominent variable relative to the extending of the drying time requirement, while spontaneous heating exhibited the least effect.

Spontaneous heating exhibited both positive and negative effects on the drying time. The reversal was attributed to chemical and biological changes which occurred during the heating period.

Hukill's analysis, when applied to the drying data, always yielded shorter computed drying times than was observed.

Drying in the bales (oriented "flat" and "on edge") occurred in very narrow and defined zones. 


\section{LITERATURE CITED}

I. Browne, Charles A., The Spontaneous Combustion of Hay, USI)A Technical Bulletin No. 141, September 1929.

2. Dawson, J. E., and F. B. Musgrave, Respiration in Hay as a Source of Heat for Barn Drying Partially Cured Hay, Agricultural I:ngineering 27: 565-6, December 1946.

3. Hall, Carl W., Drying Farm Crops. Reynoldsburg, Ohio: Agricultural Consulting Associates, Inc., 1957. 212-79.

4. Hendrix, A. T., Heat Generated in Chopped Hay and Its Relation to the Drying Effect, Agricultural Engineering 28: 286-8, July 1947.

5. Henson, E. R., Curing and Storage of Alfalfa Hay, Iowa Experiment Station Research Bulletin No. 251., February 1939.

6. Hoffman, E. J., Oxidation and Gas Formation in Spontaneous Heating of Hay, Journal of Agricultural Research 5i(6): 527-46, 1935.

7. Hukill, William V., Basic Principles in Dry ing Corn and Grain Sorghum, Agricultural Engineering 28: 335-8, 340, August 1947.

8. James, Lawrence H., Leo F. Rettger, and Charles Thom, Microbial Thermogenesis--Heat Production in Moist Organic Materials with Special Reference to the Part Played by Micro-Organisms, Journal of Bacteriology 15: 117-41, 1928.

9. Jennings, B. A., Mow Curing of Hay, Agricultural Engineering 14:156.

10. Phillips, Ross A., Factors Involved in the Rapid Drying of Hay, Paper No. NA62-525 presented at North Atlantic Section Meeting ASAE, Morgantown, West Virginia, August 1962.

11. Rothbaum, H. P., Spontaneous Combustion of Hay, Journal of Applied Chemistry 13: 291-302, July 1963.

12. Sherwood, T. K., The Drying of Solids I, Industrial and Engineering Chemistry 21: 12-6, January 1929.

13. Snedecor, George W., Statistical Methods. Ames, Iowa: The Iowa State College Press, 1959. 122-6, 413-47.

14. Terry, C. W., Some 1947 Results of Barn Hay Drying, Agricultural Engineering 29: 208-9, 214, May 1949. 


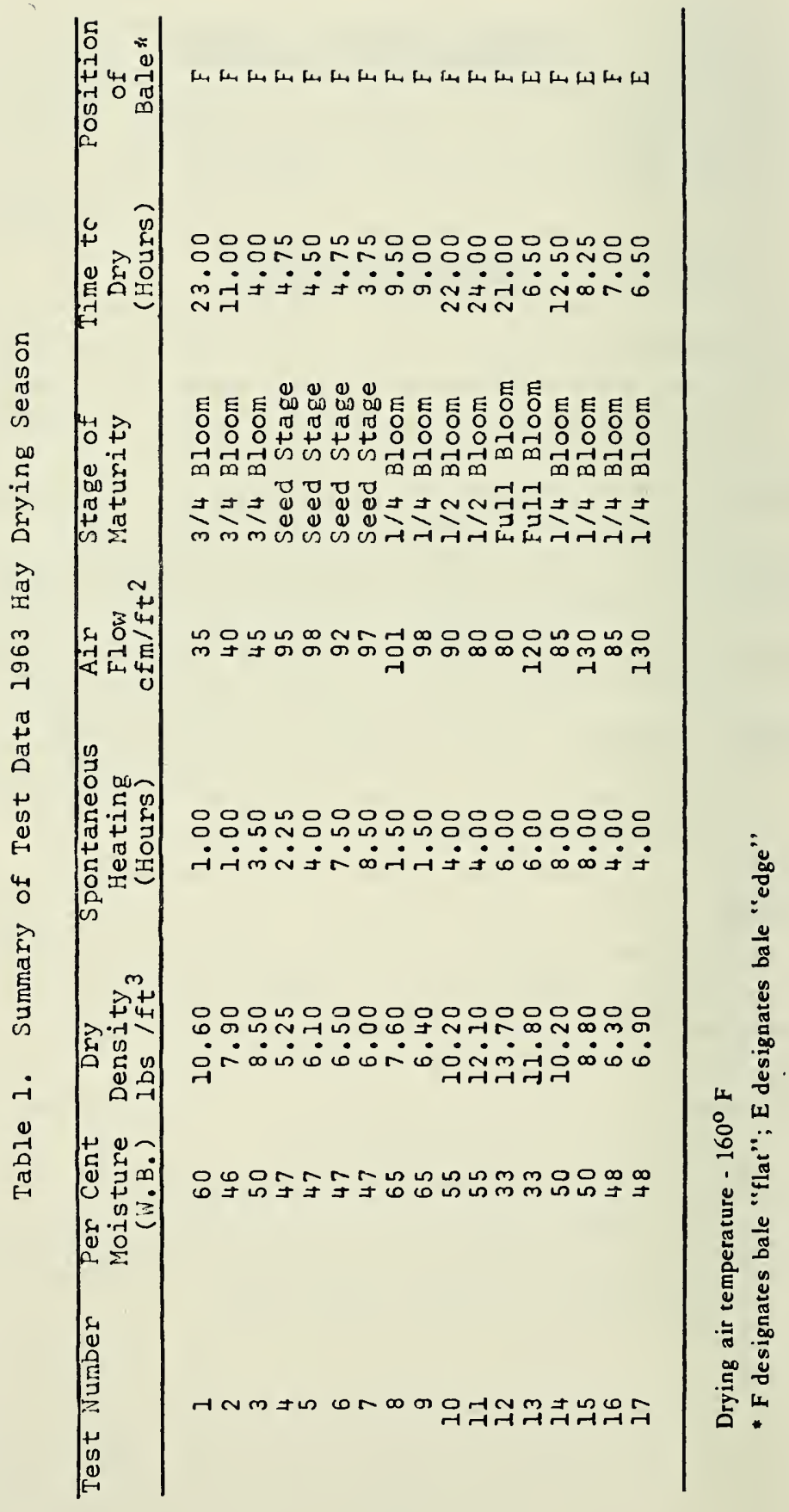




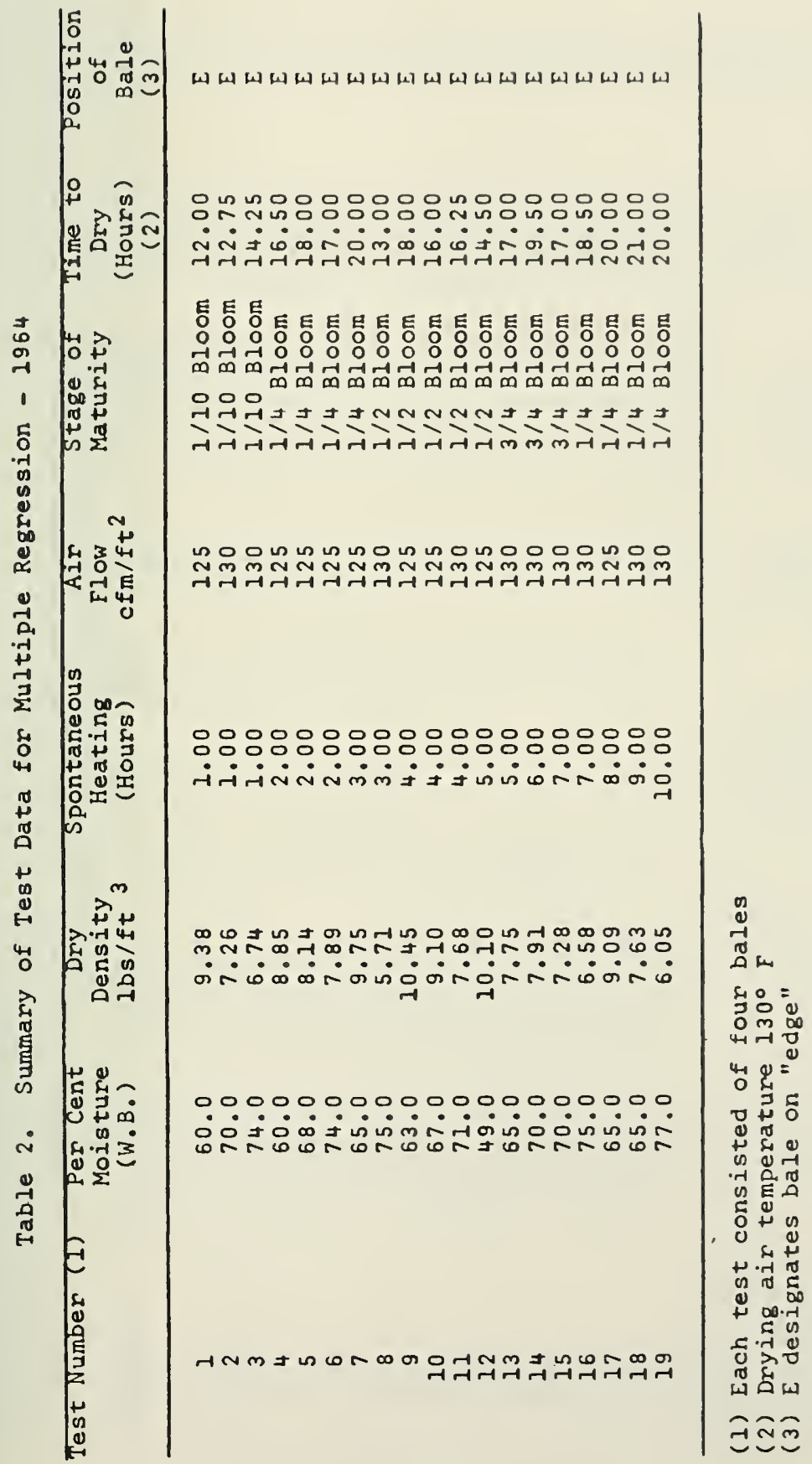




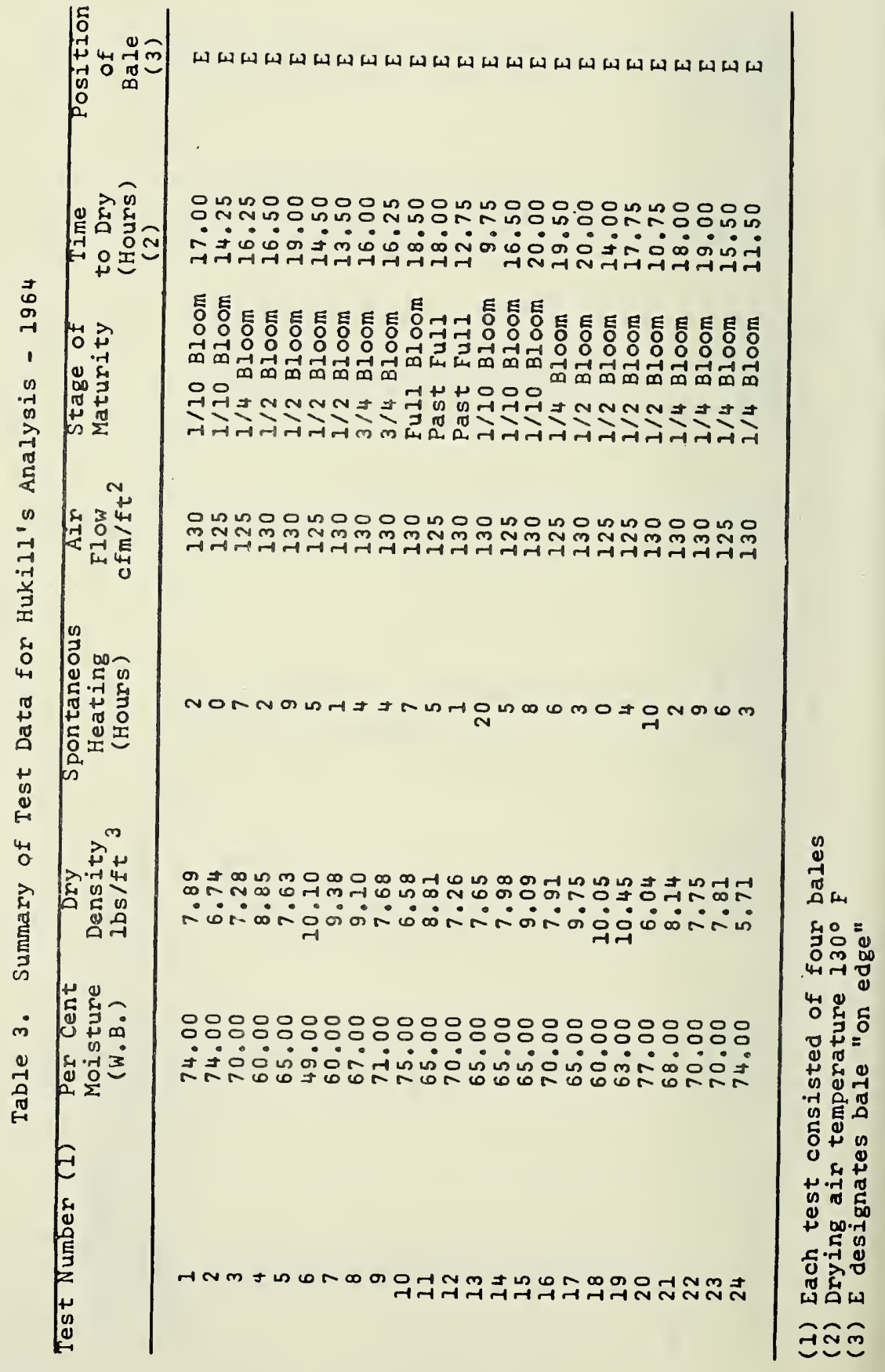




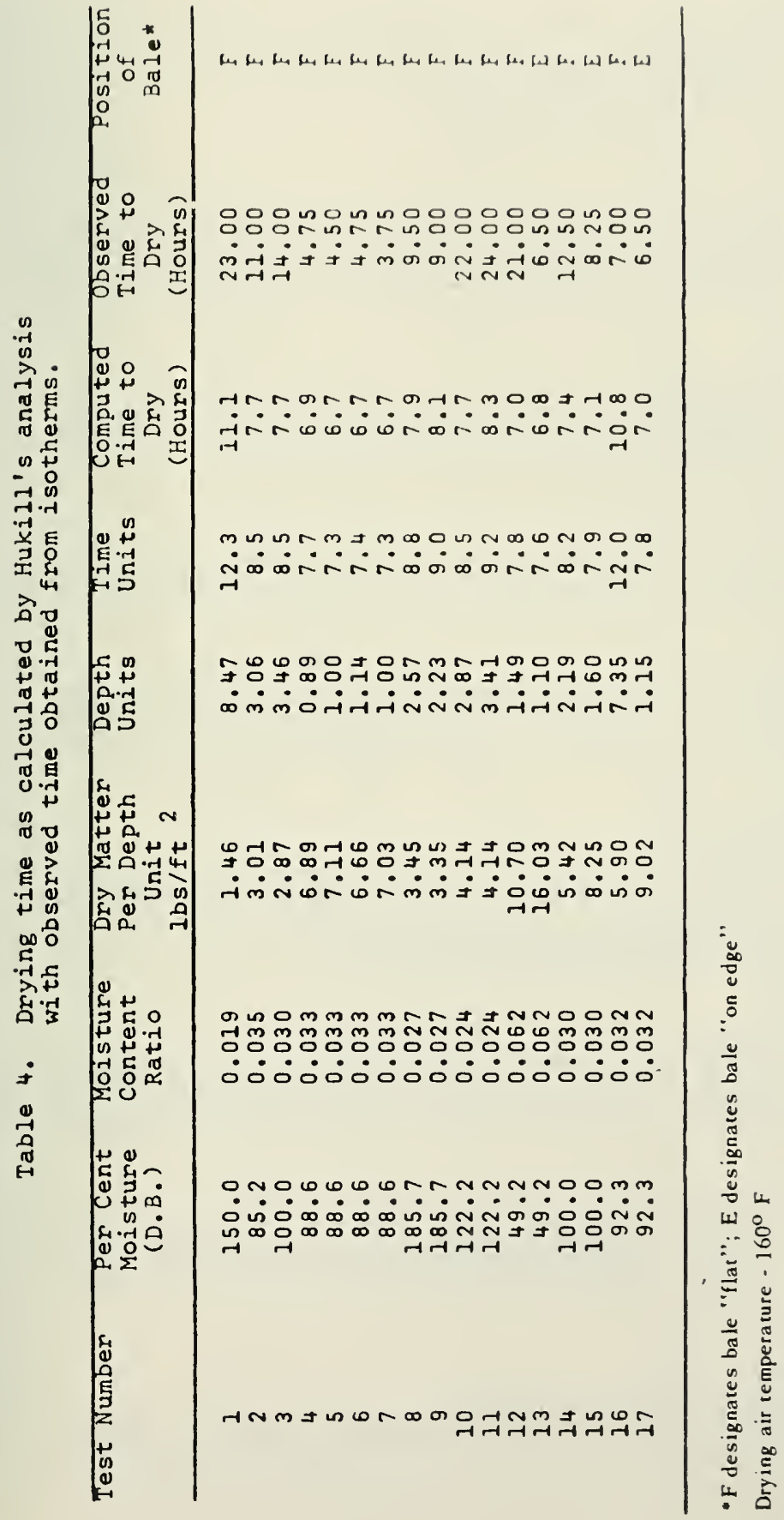




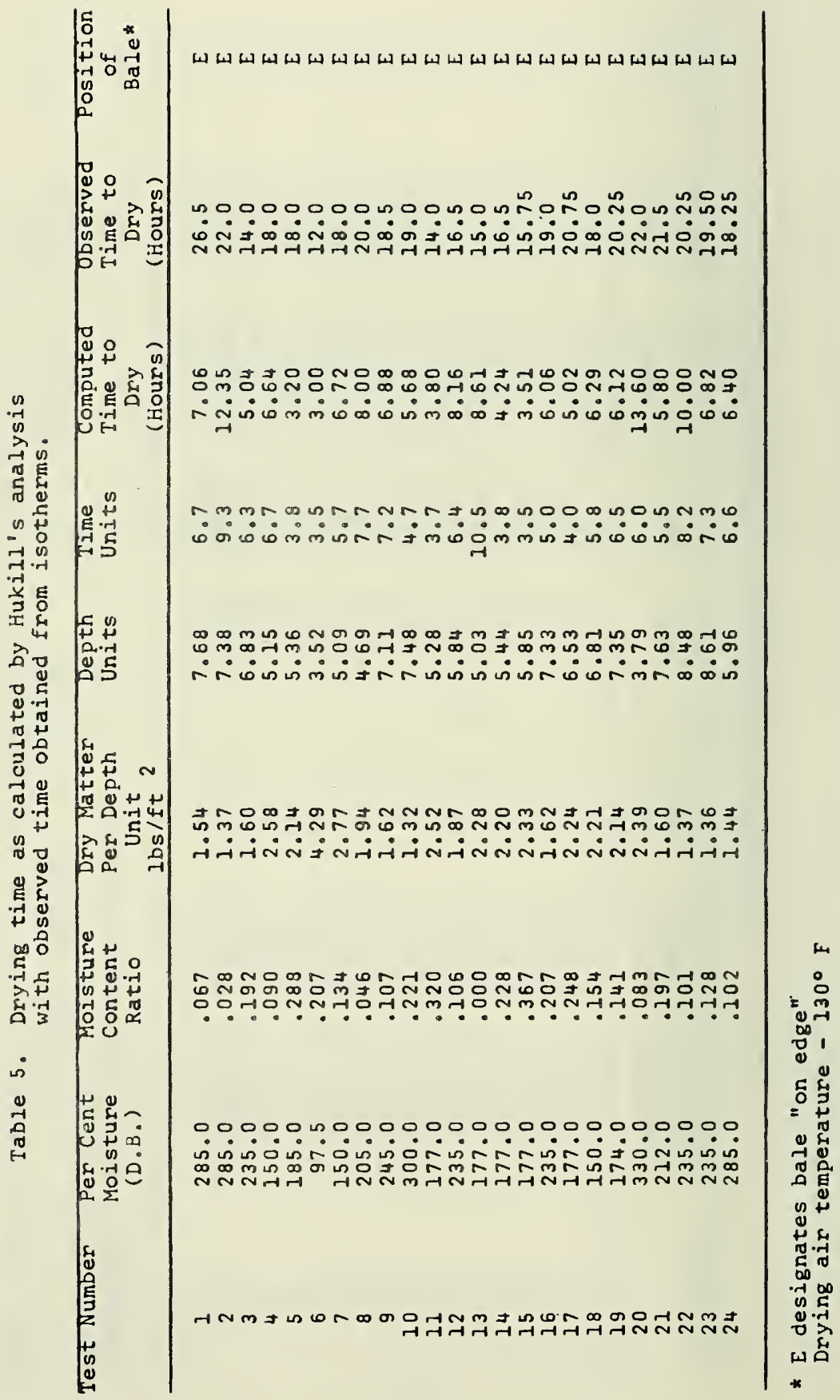




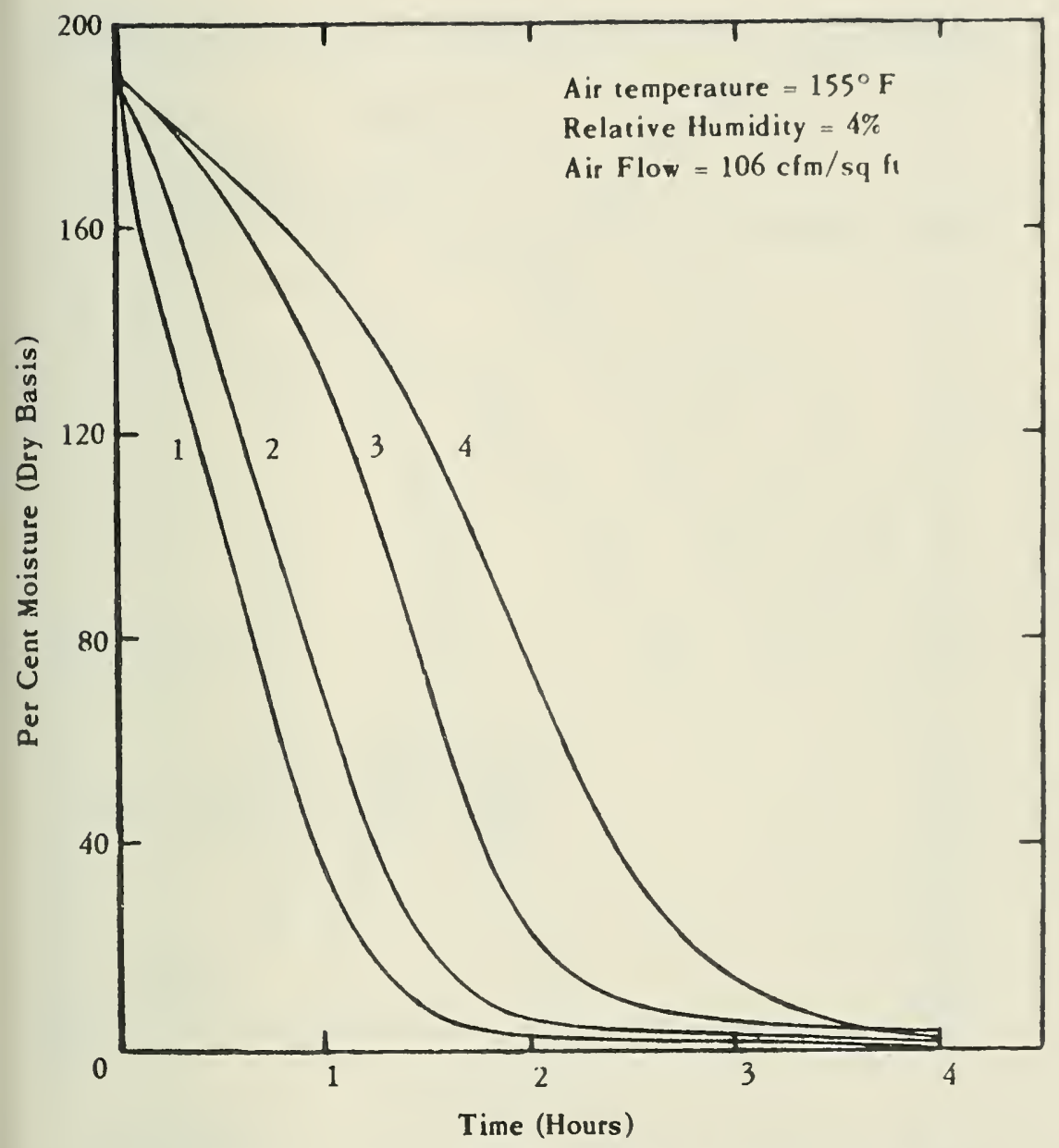

Figure 1. Moisture curves of the four samples in series in the same air stream. 


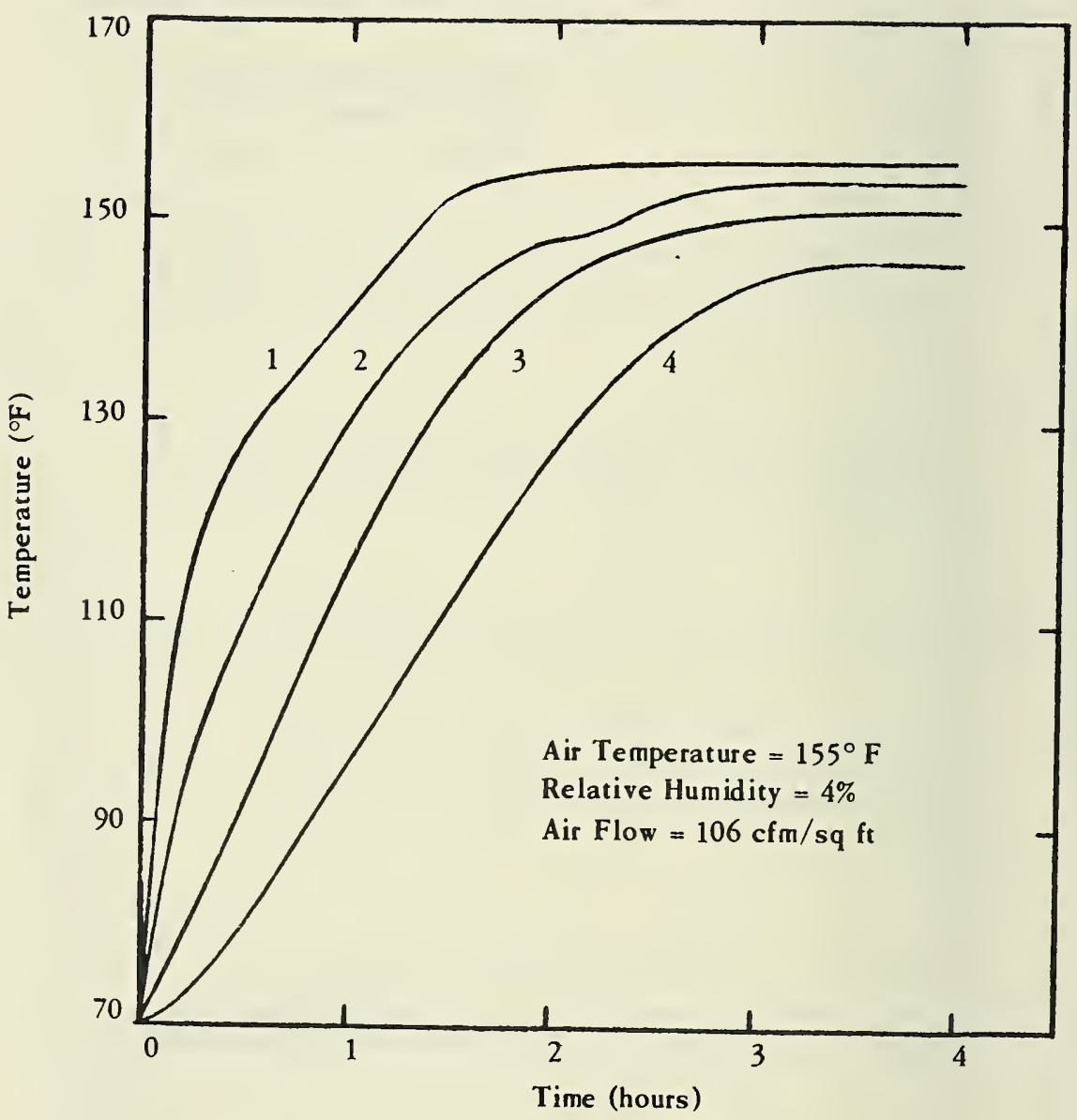

Figure 2. Temperature curves of four samples in series in the same a ir stream. 


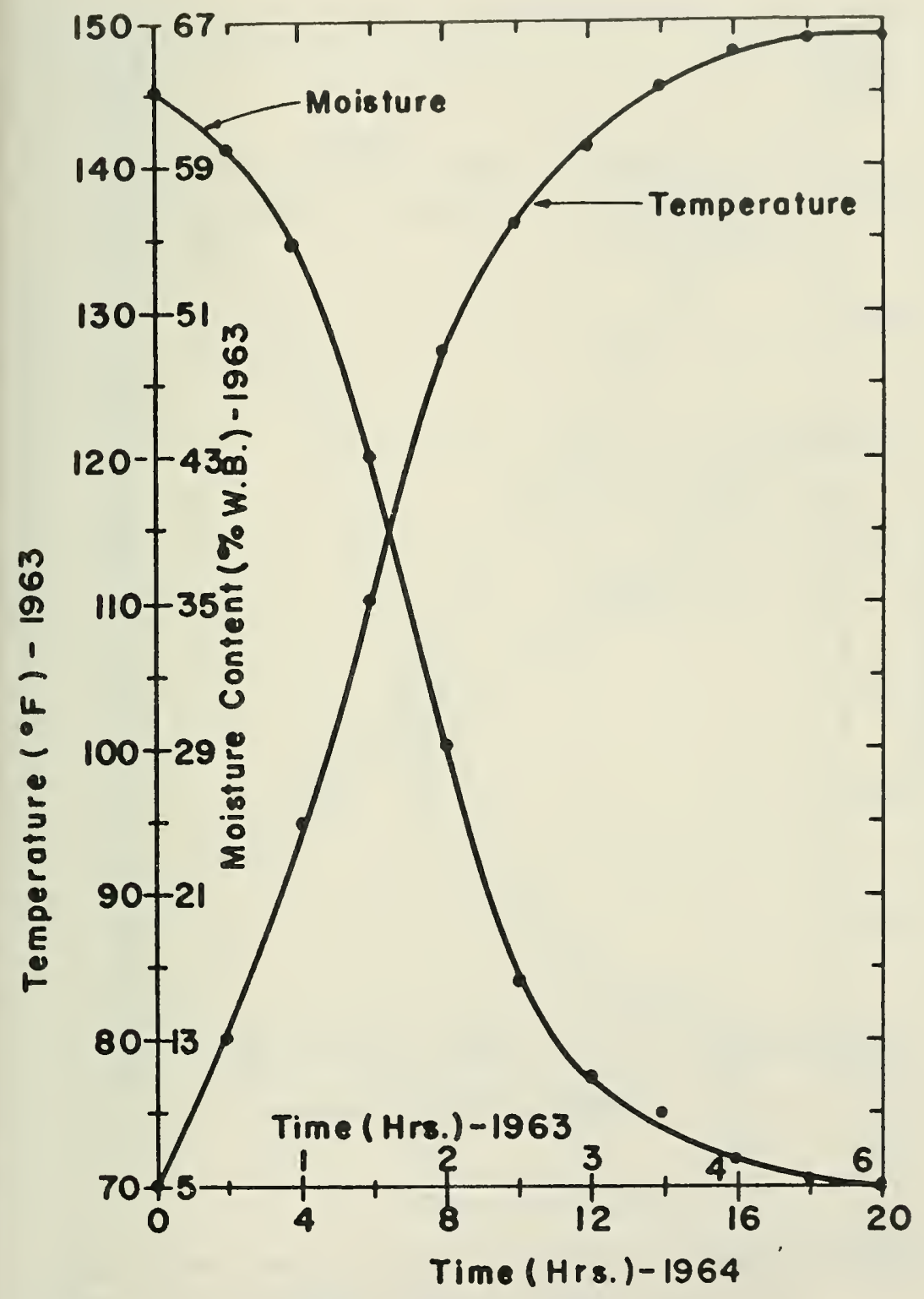

Figure 3. Variation of moisture content and temperature with time. 


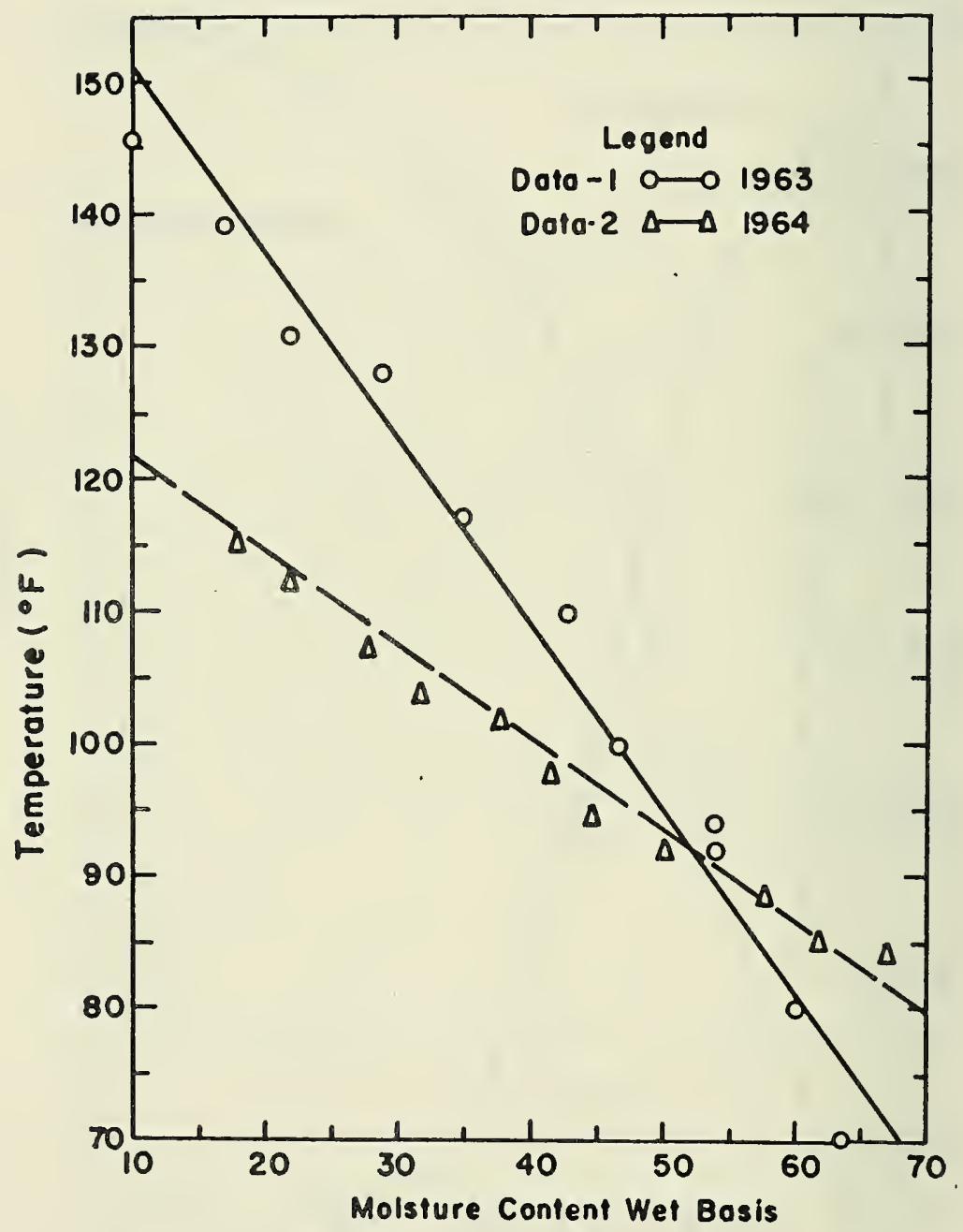

Figure 4. Plot of moisfure content versus temperafure for two separate drying systems and seasons. 


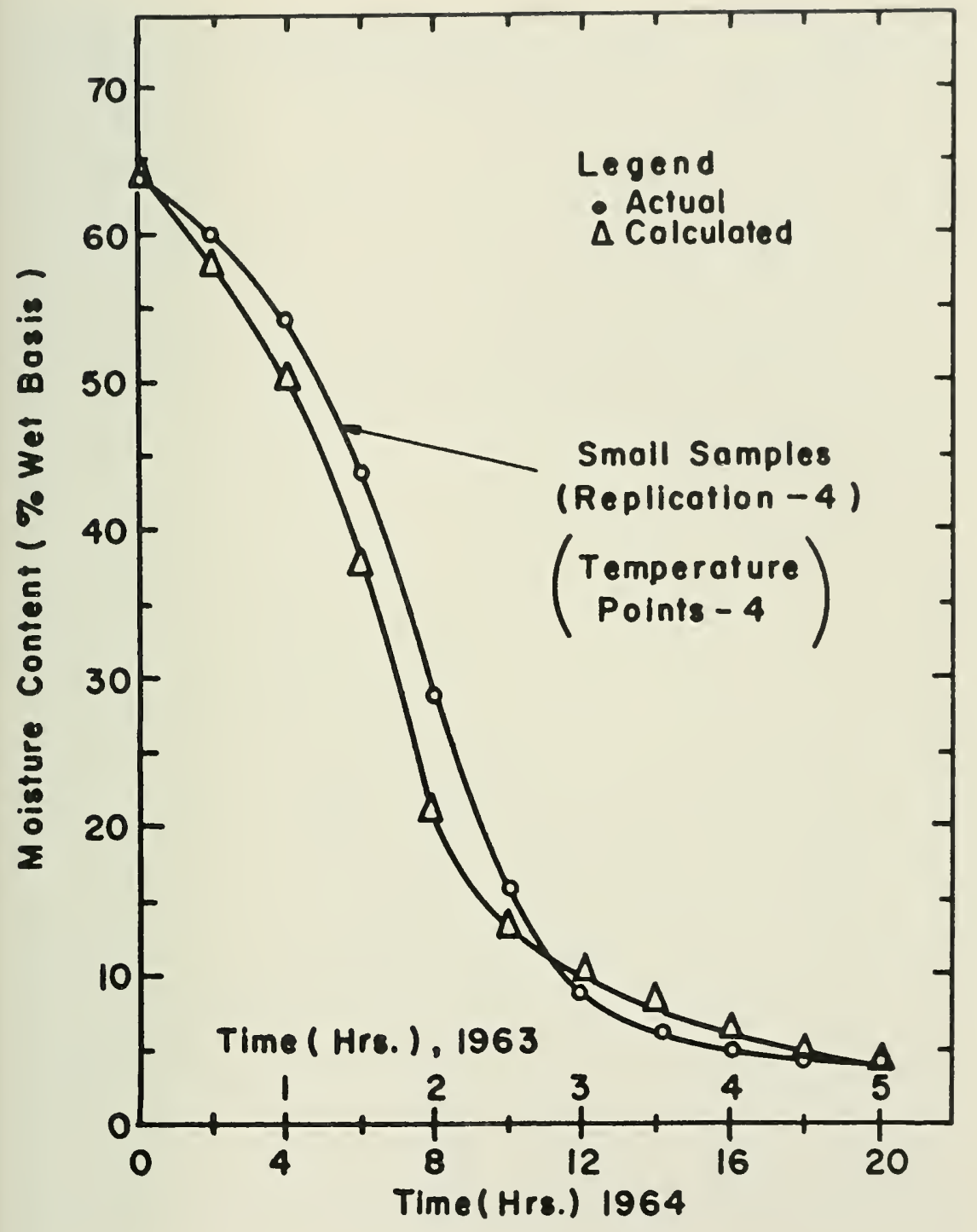

Figure 5. Actual and Colculated drying curves for two drying systems ond two different seosons. 


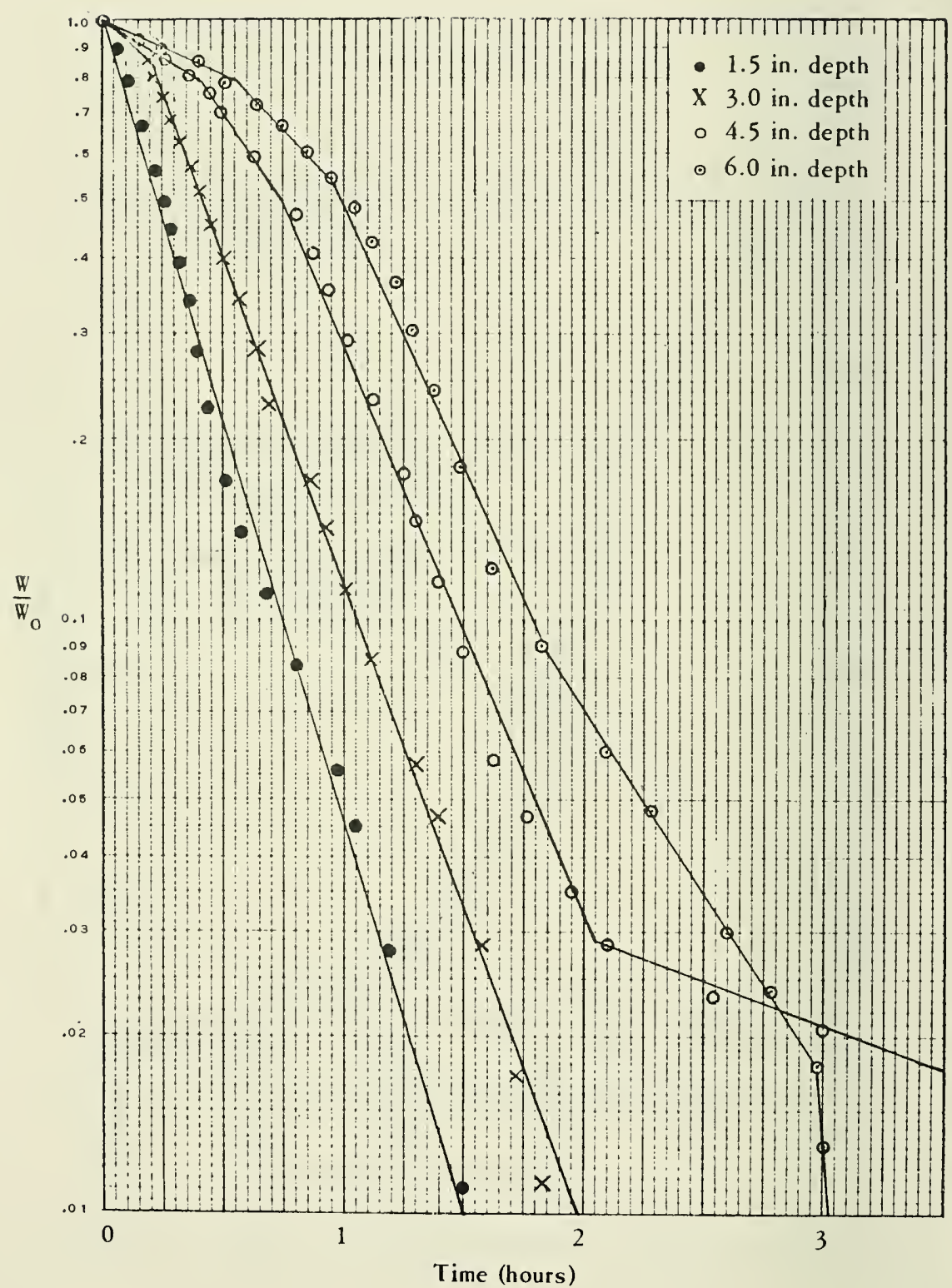

Figure 6. Relationship of time and $W / W$ equal to the moisture at start of test. 


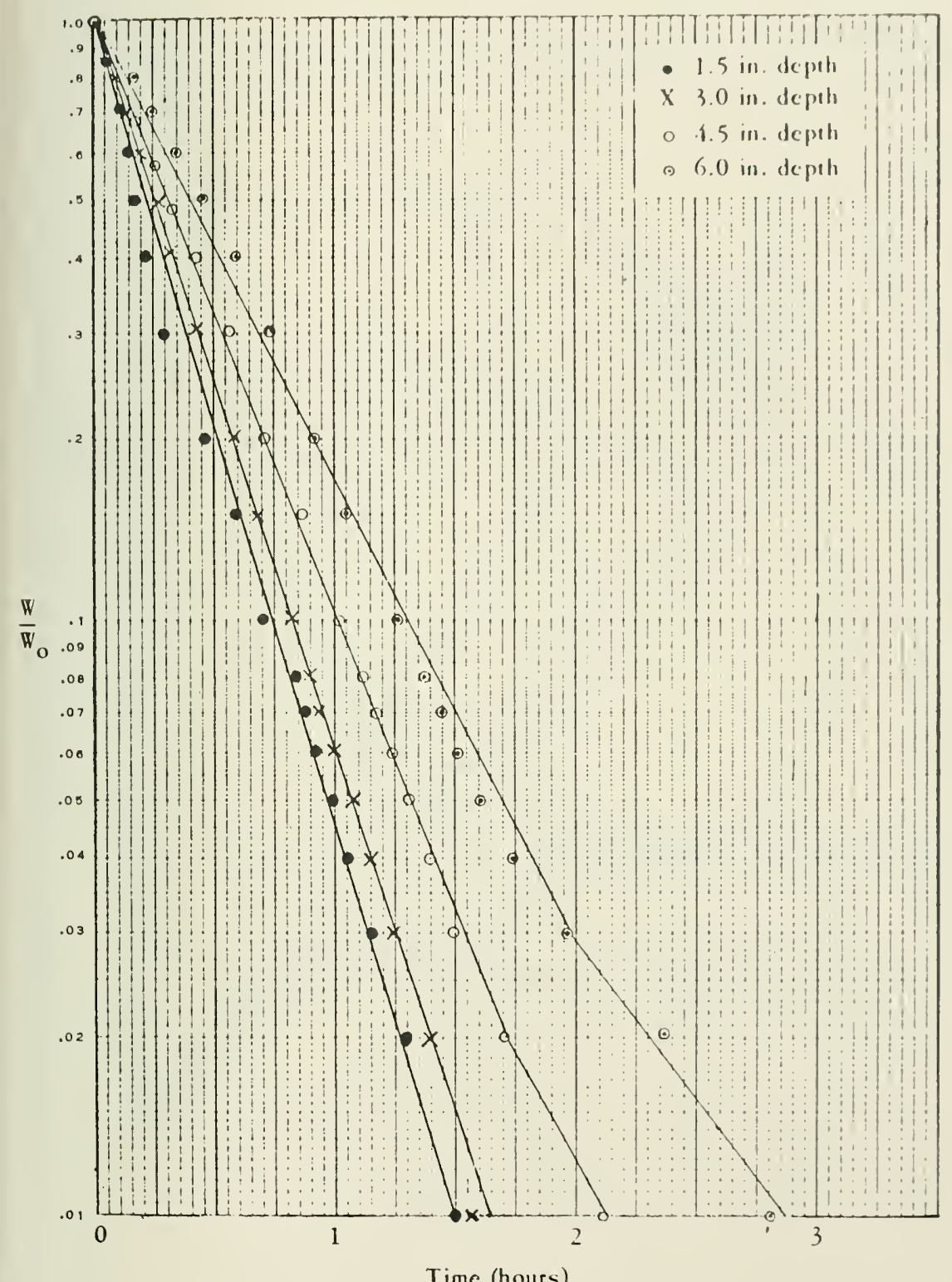

Figure 7. Relationship of time and $\mathbb{H}^{\prime} / \mathbb{H}_{0}$ equal to 0.6 the moisturc at start of test. 


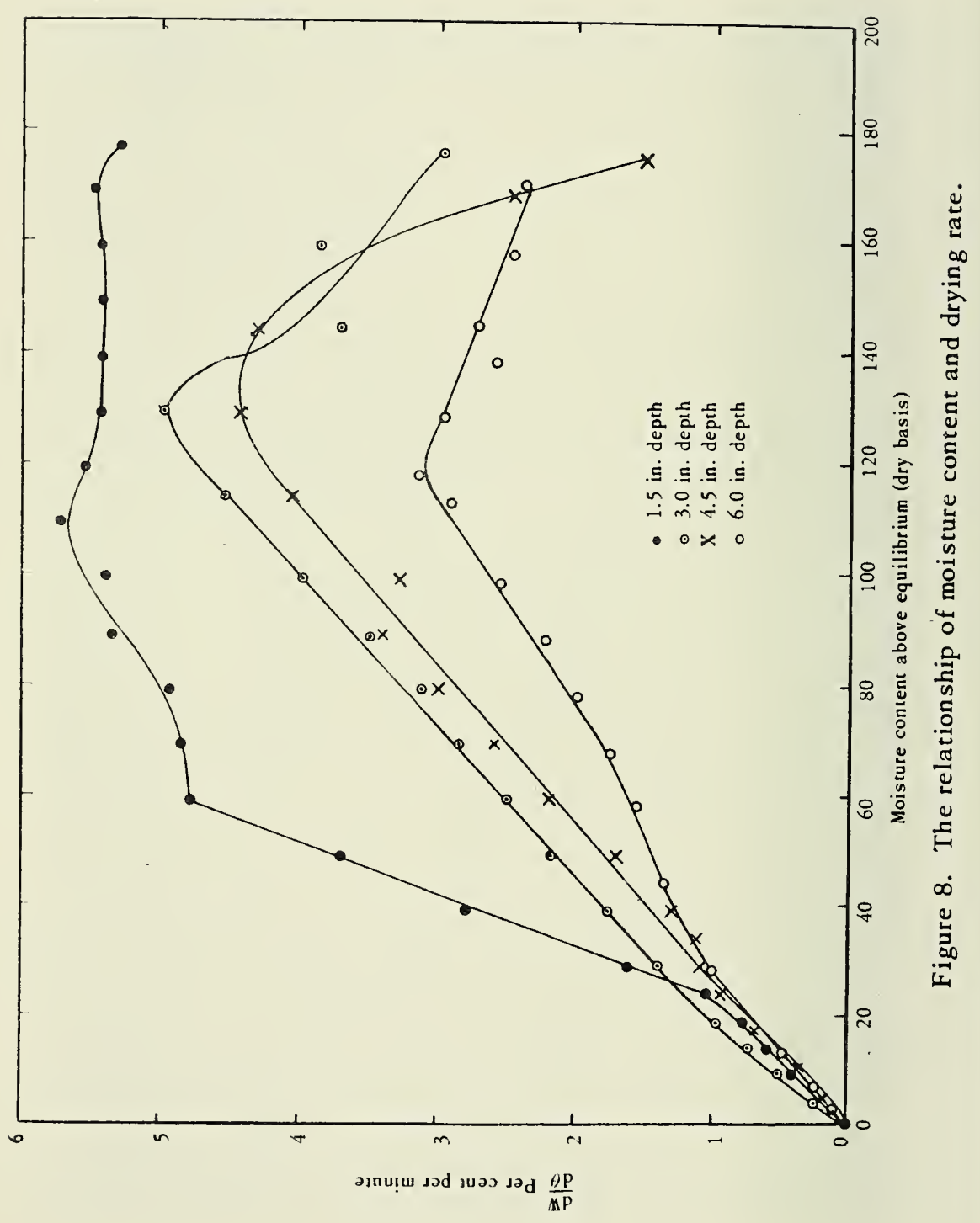




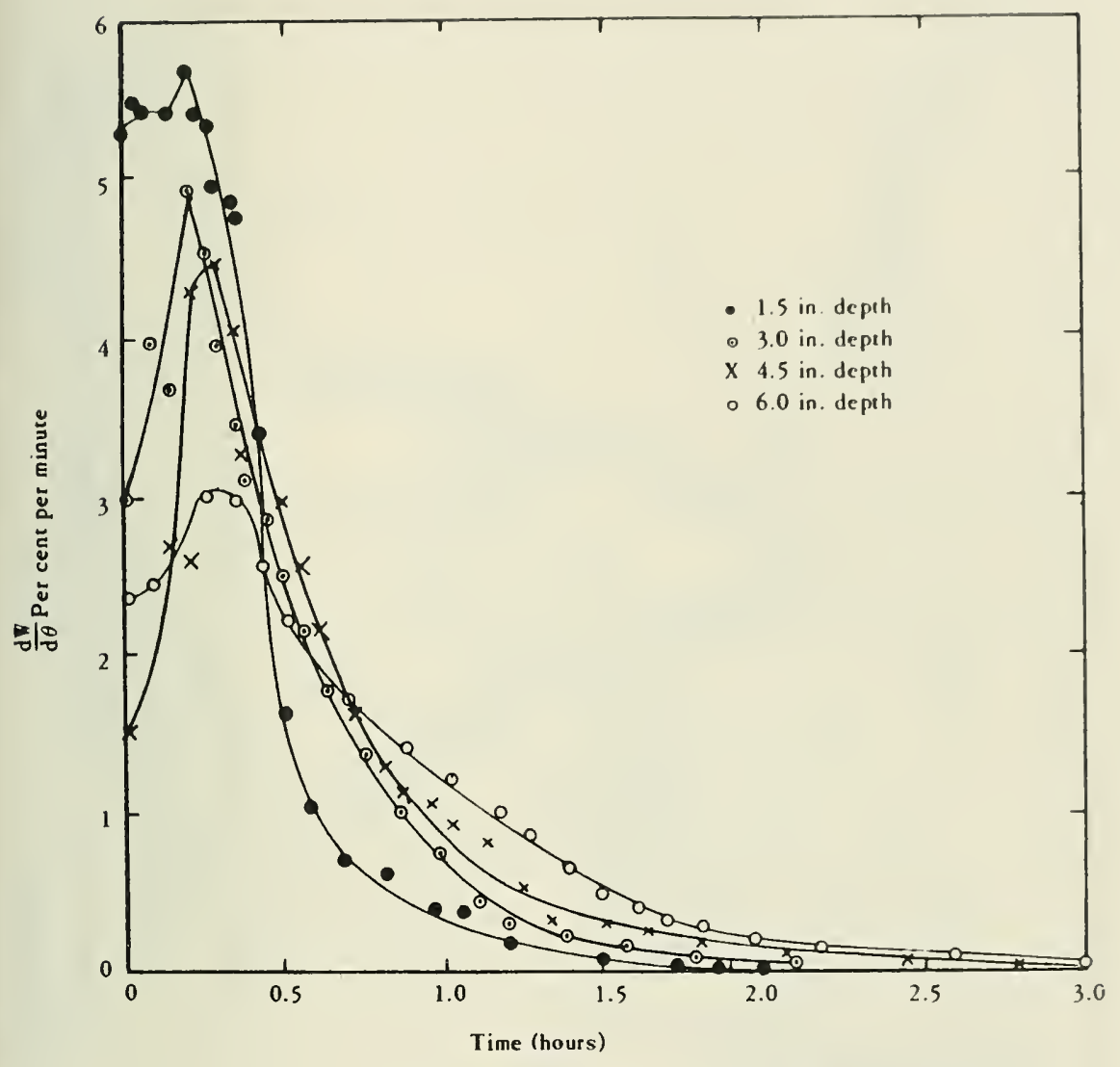

Figure 9. The relationship of time and drying rate. 


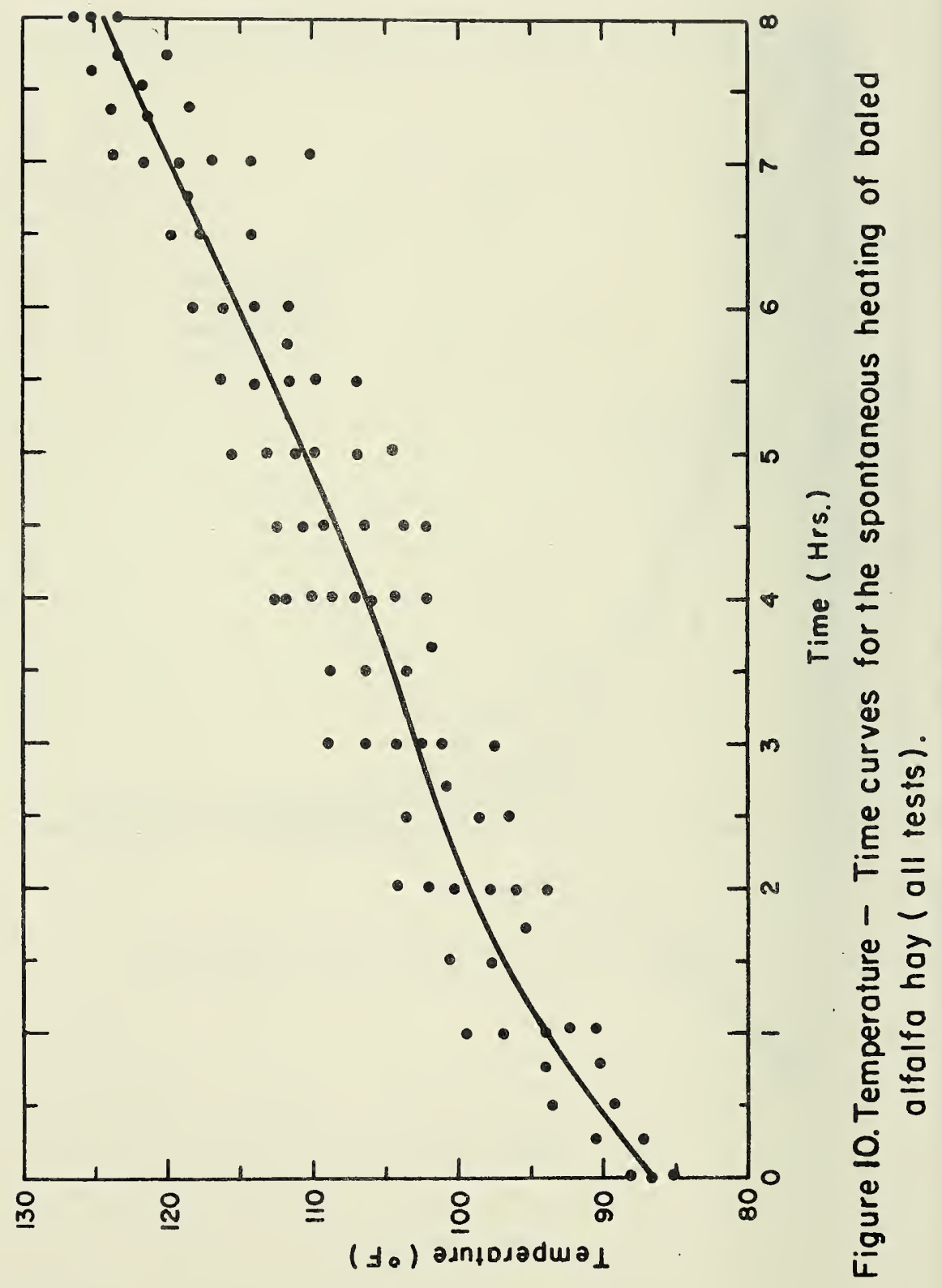




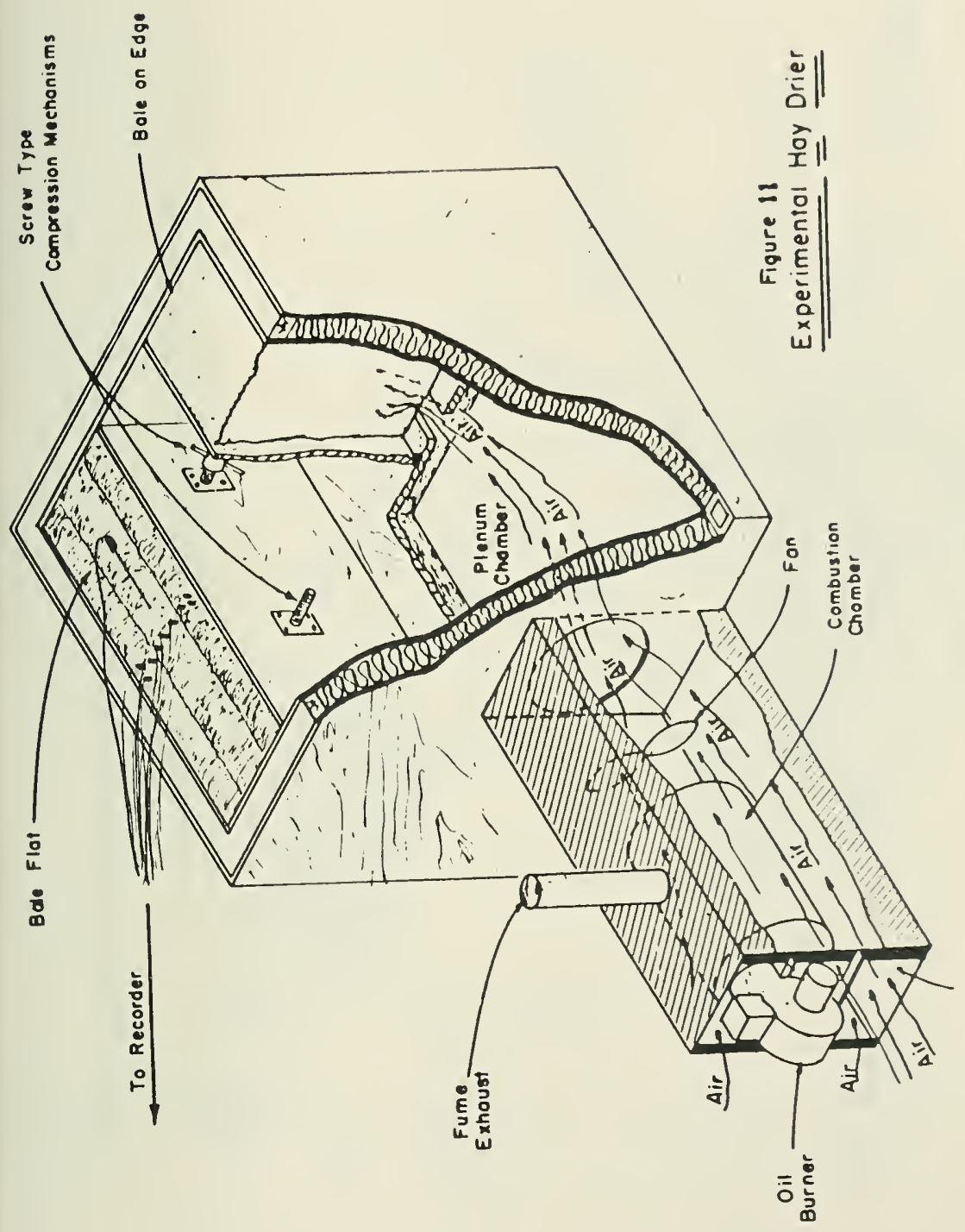




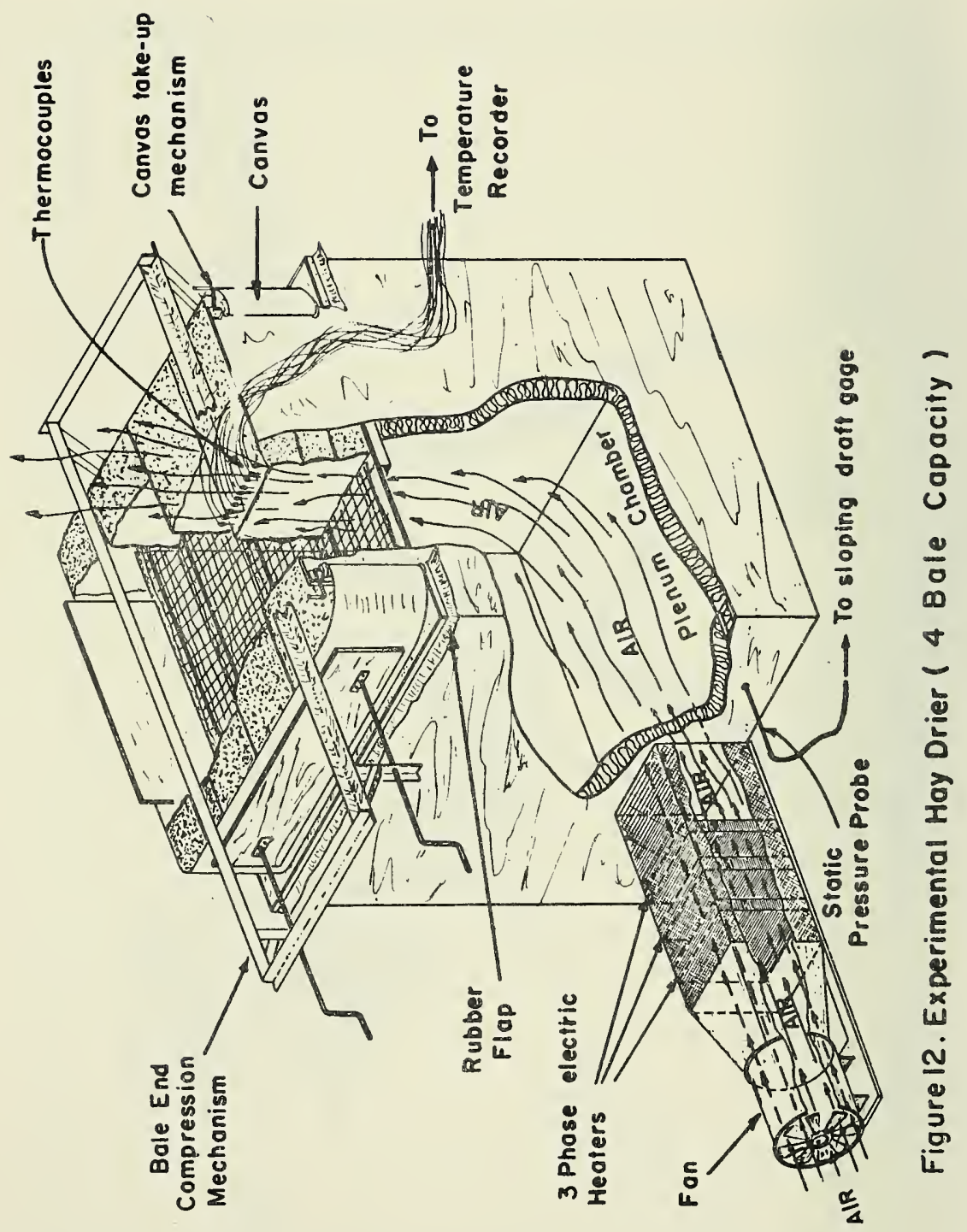



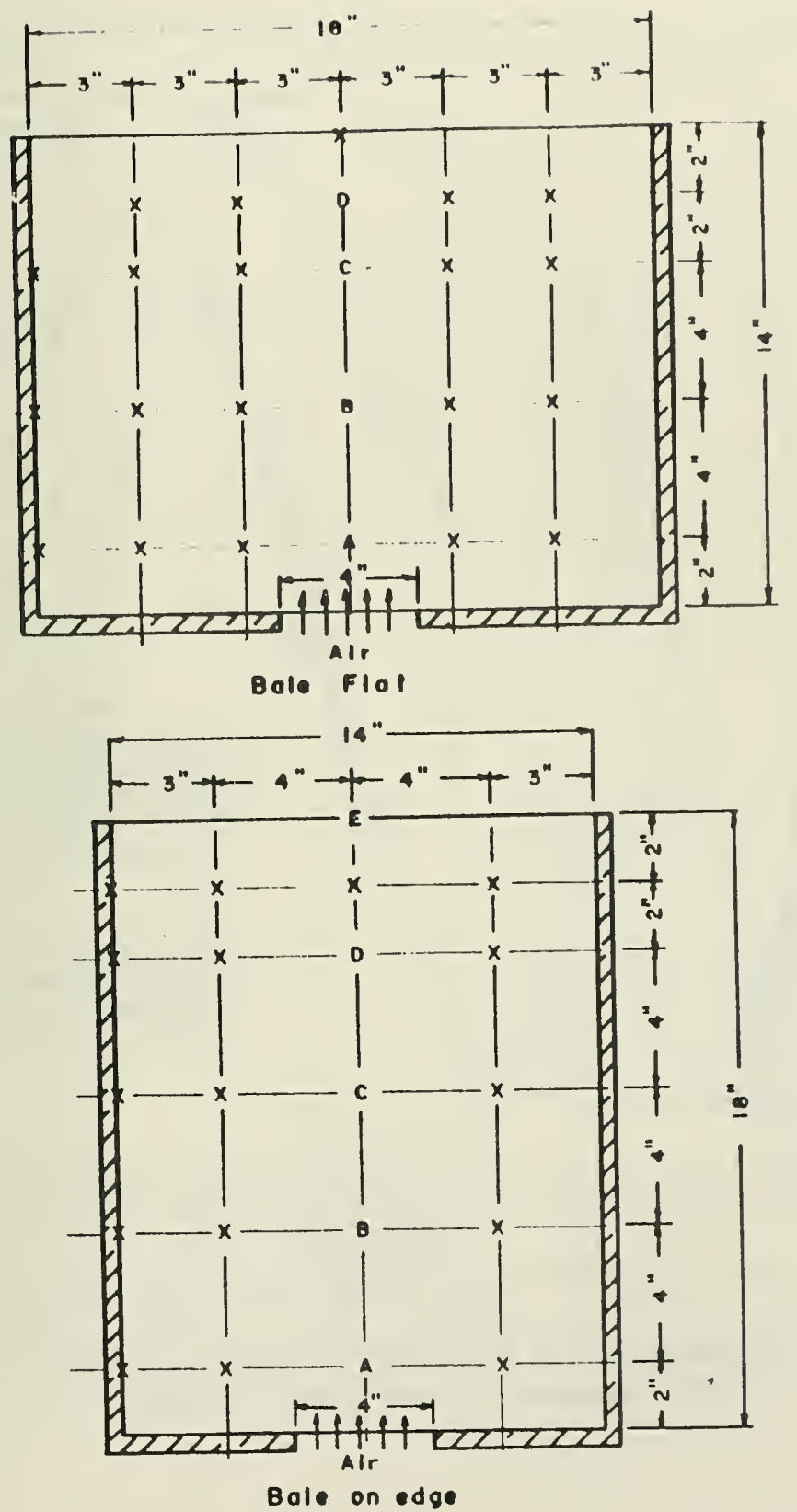

Figure 13. Grid system used for measuring temperatures with thermocouples. 


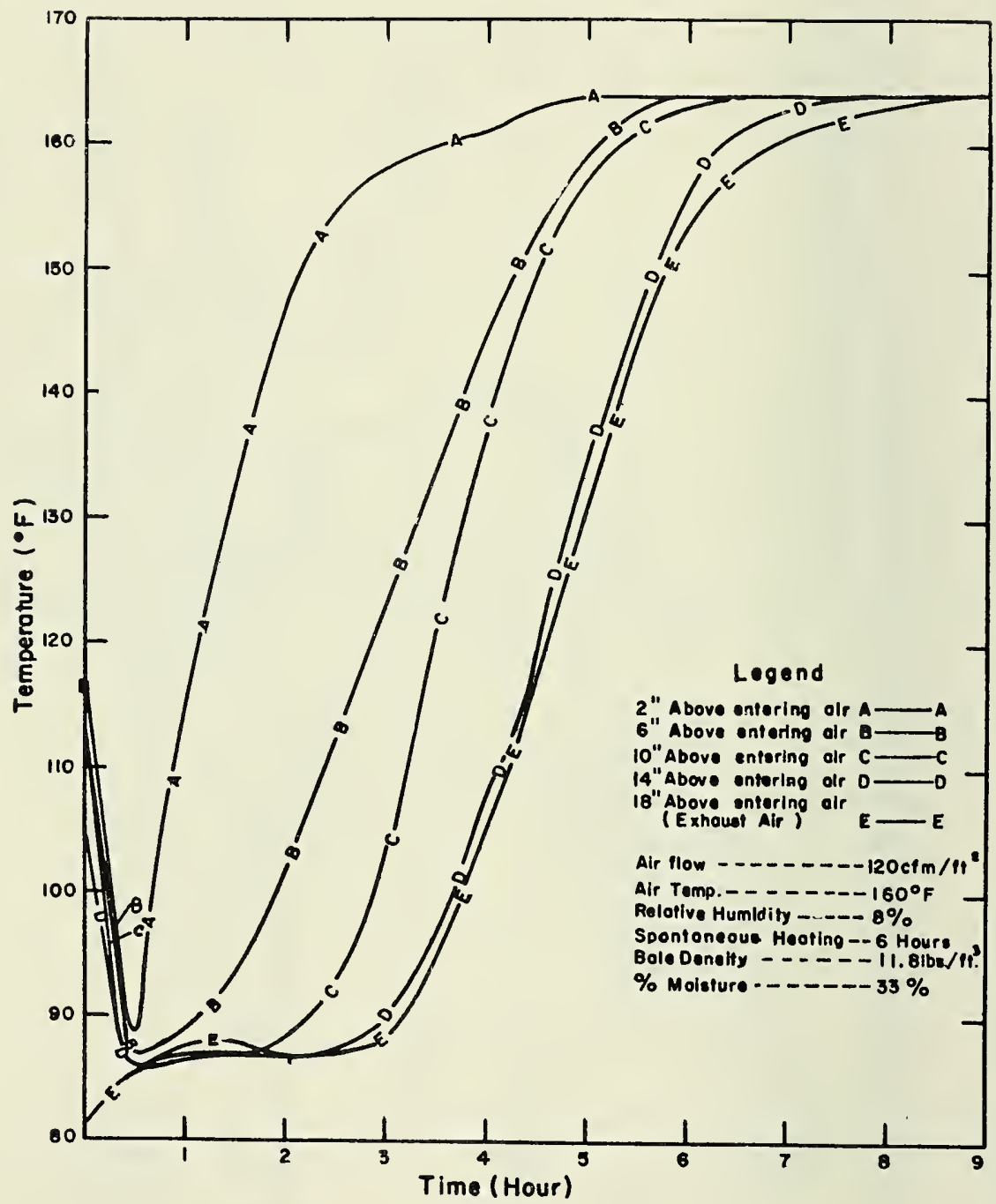

Figure 14. Temperatures for different points located on o vertical line in center of bale (Bale on edge). 


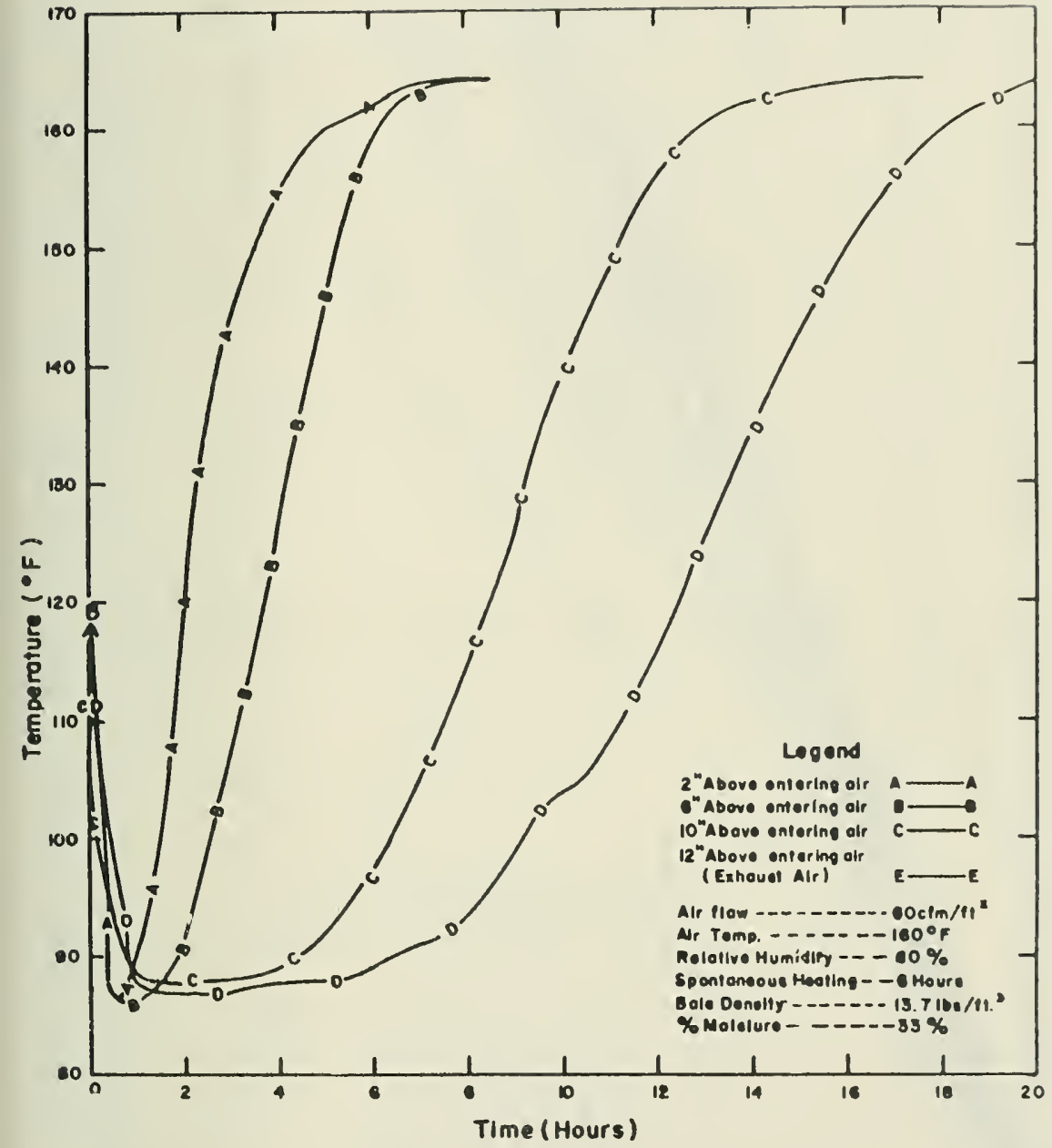

Figure 15. Temperatures for different points located on a verfical line in center of bole (Bale Flat). 


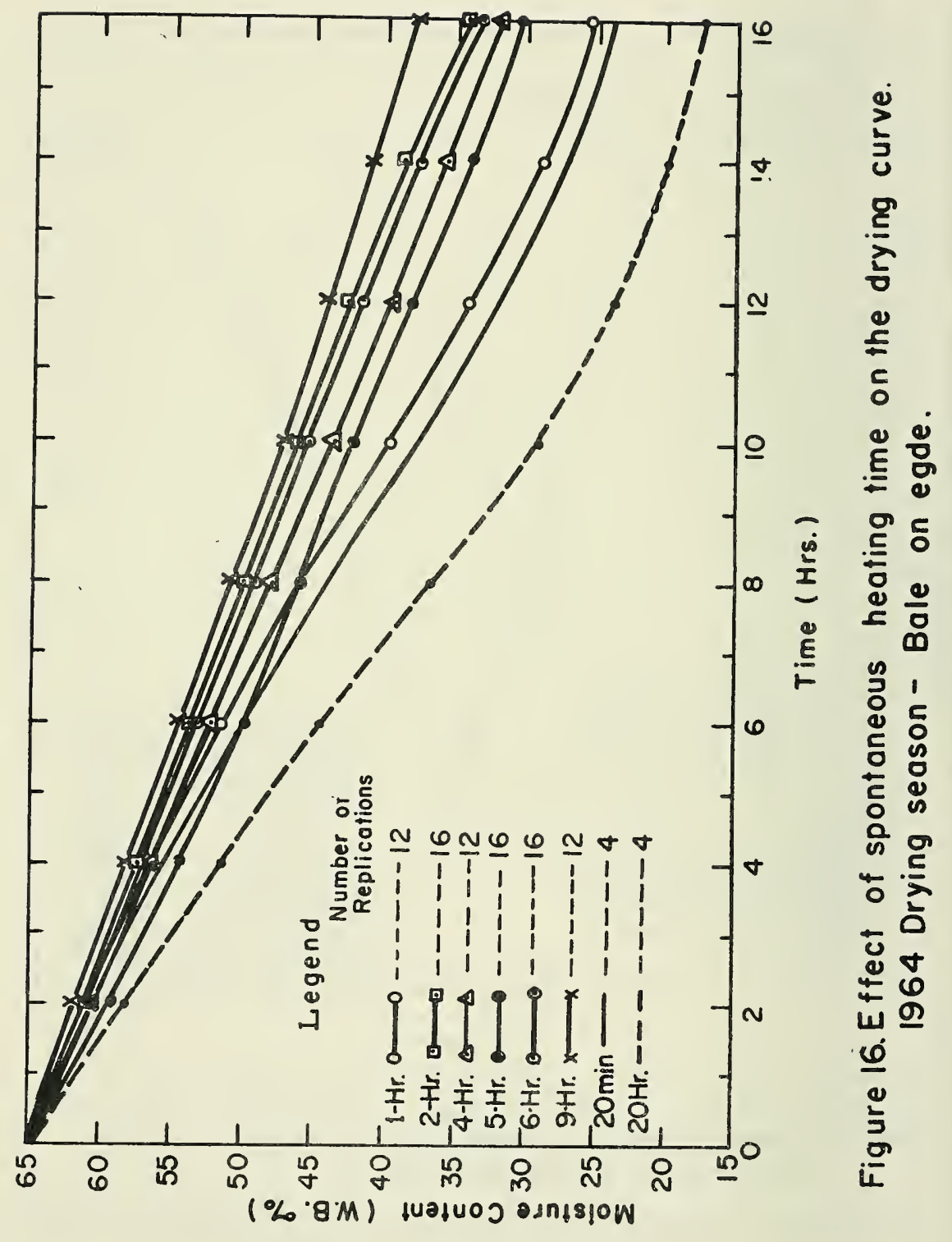




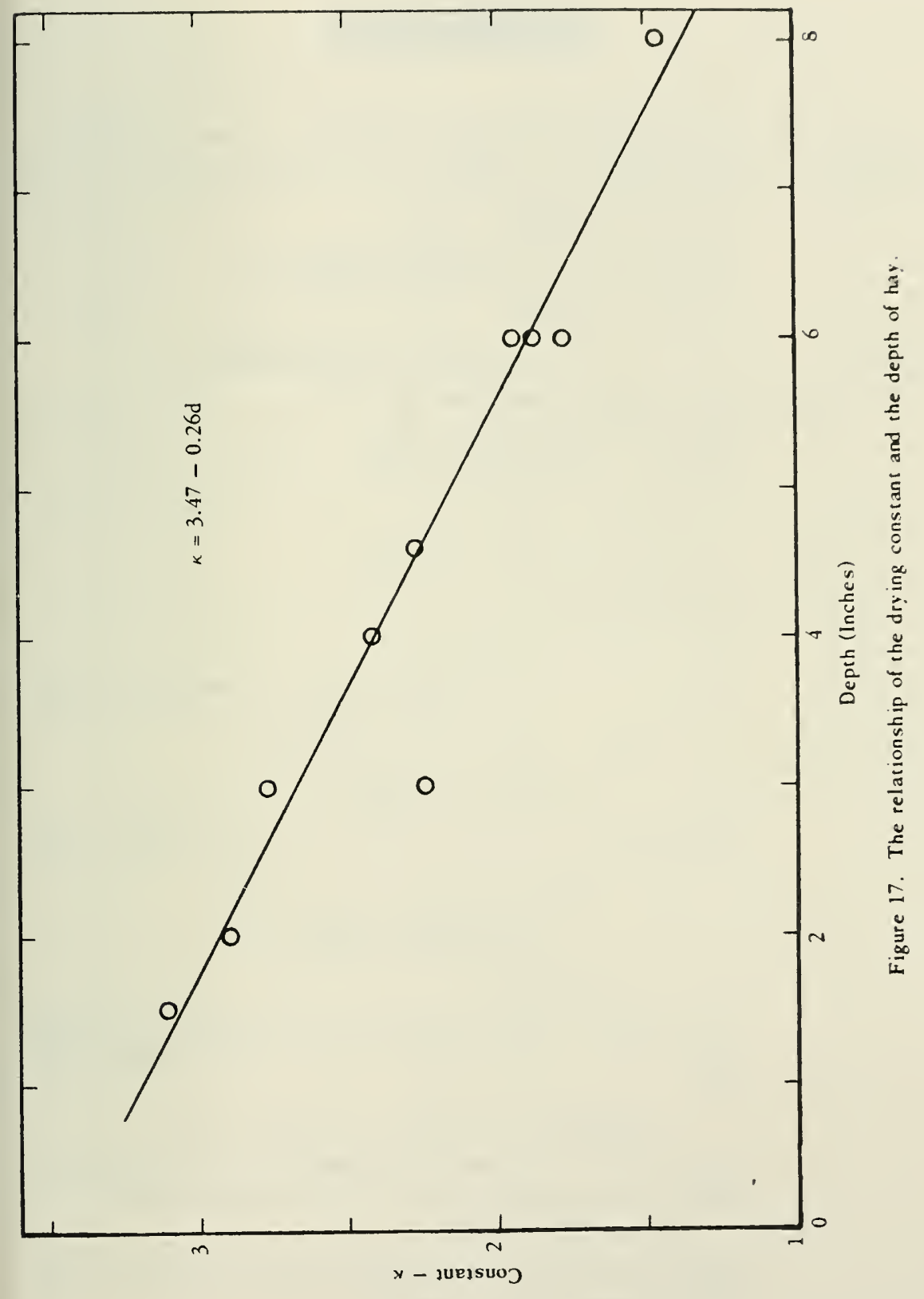




\section{APPENDIX A}

Sample Calculation for Computing

Drying Time by Hukill's Analysis

Given:

Initial Moisture Content $=92.3 \%$ (D. B.)

Drying Temperature $=160^{\circ} \mathrm{F}$

Relative Humidity $=9 \%$

Dry Top Layer to $7 \%$ Moisture (D. B.)

Density $=6.9 \mathrm{lb} / \mathrm{ft}^{3}$

Find:

Time Necessary to Dry for Given Conditions

Solution: $\quad$ From a psychrometric chart

Wet Bulb Temperature $=77^{\circ} \mathrm{F}$

Specific Volume $=16.1 \mathrm{ft}^{3} / \mathrm{lb}$

$\Delta \mathrm{T}=160-77=83^{\circ} \mathrm{F}$

From work by Davis, et. al. (4)

Equilibrium Moisture $=4.8 \%(\mathrm{D} . \mathrm{V}$.

Value of $\mathrm{H}=0.9$

$\Delta \mathrm{M}=92.3-4.8=87.5 \%$

The Moisture Content Ratio (MCR) is determined by Equation 2.

$$
\text { MCR }=\frac{7.0-4.8}{92.3-4.8}=\frac{2.2}{87.5}=.025
$$

The pounds in a depth unit may be calculated using Equation 1.

$$
\begin{aligned}
G & =\frac{(130 / 16.1) 60 \times 83 \times 0.24 \times 0.9}{0.01 \times 87.5 \times 1100} \\
& =9.02 \mathrm{lb} / \mathrm{ft}^{3}
\end{aligned}
$$

The number of depth units may be calculated by dividing the weight of hay per square foot by the computed value of $\mathrm{G}$.

Depth units $=(18 / 12) \times(6.9 / 9.02)=1.15$

From Figure 4 the number of time units can be determined using the computed values of MCR and depth units.

Time units $=7.8$

The drying time is now determined by multiplying the number of time units by the value $\mathrm{H}$.

$$
\begin{aligned}
\text { Time } & =7.8 \times .9 \\
& =7.0_{2} \text { hours }
\end{aligned}
$$




\section{APPENDIX B}

Moisture Determination

Moisture content is reported with two different bases. These bases are (a) dry weight basis (D. B.) and (b) wet weight basis (W'. B.). The per cent moisture may be represented by one of the following equations:

$$
\begin{aligned}
& M_{(\text {W.B. })}=\frac{\text { Weight of the water }}{\text { Total weight of solid }} \times 100 \\
& M_{(\text {D.B. })}=\frac{\text { Weight of the water }}{\text { Dry weight of the solid }} \times 100
\end{aligned}
$$

Conversion from one base to the other may be given as follows:

$$
M_{(\mathbb{W} . \text { B. })}=M_{(D . B .)} /(100+M)(D . B .)
$$

The relation between the two bases is shown in Figure 18. 


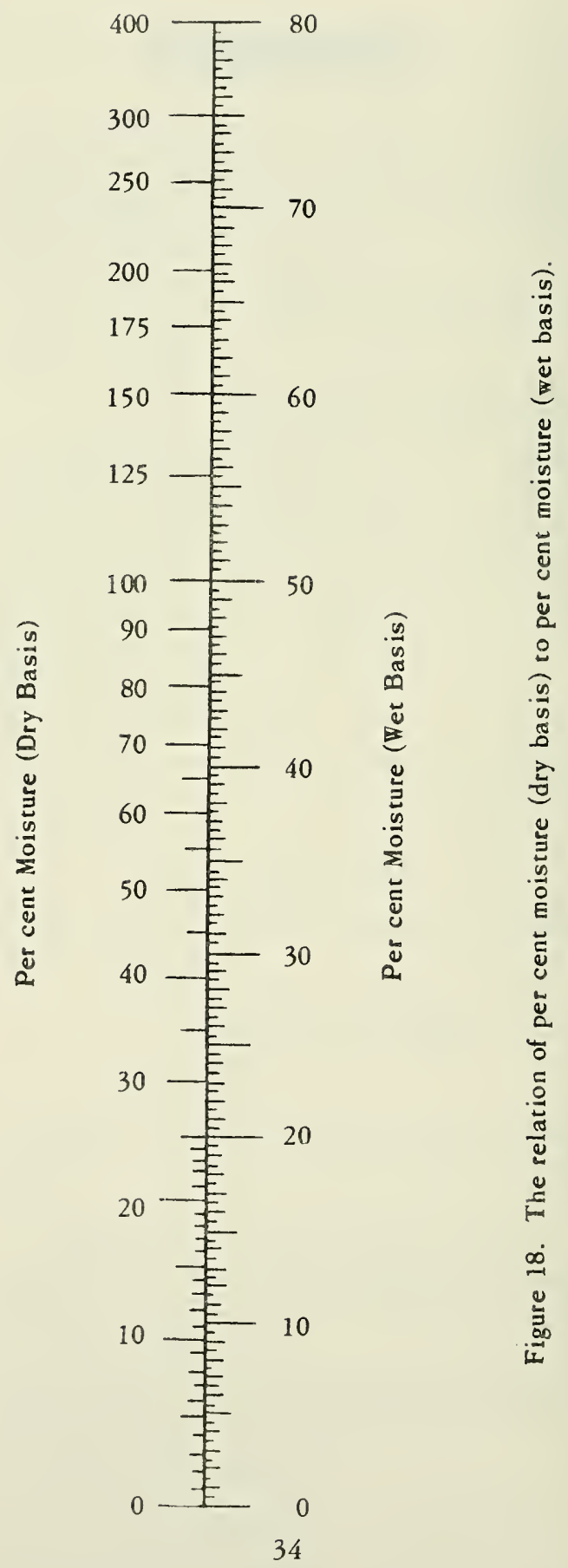




\section{APPENDIX C}

ISOTHERMS FOR SELECTED TIME INTERVALS

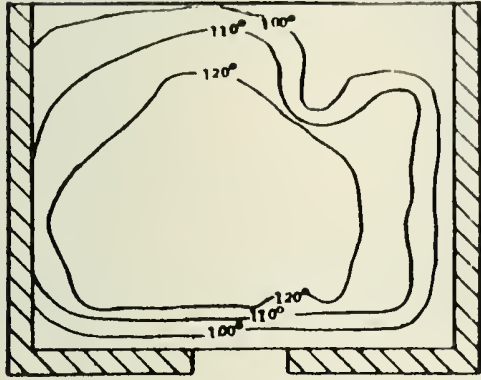

After 4 Hours Spontaneous Heating

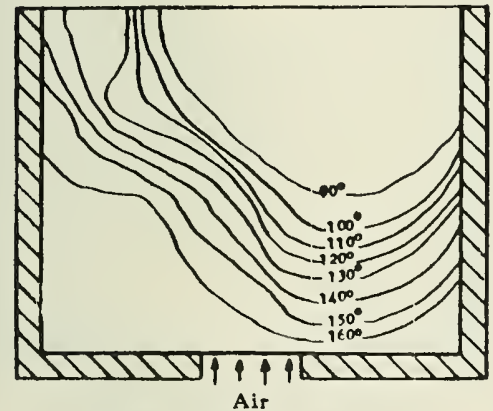

After 2 Hours of Air Flow

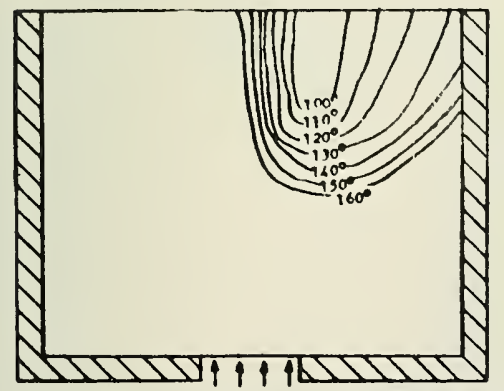

Ais Air Flow-85 cfm/ $/ \mathrm{ft}^{2}$

Relative Humidity $-9 \%$

Density $-6.3 \mathrm{lbs} / \mathrm{ft}^{3}$

Per cent Moisture- $48 \%$ After 6 Hours of Air Flow

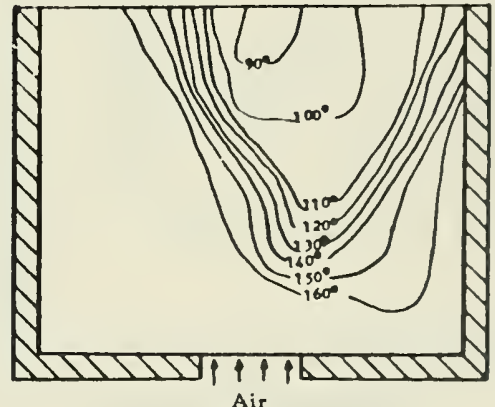

After 4 Hours of Air Flow

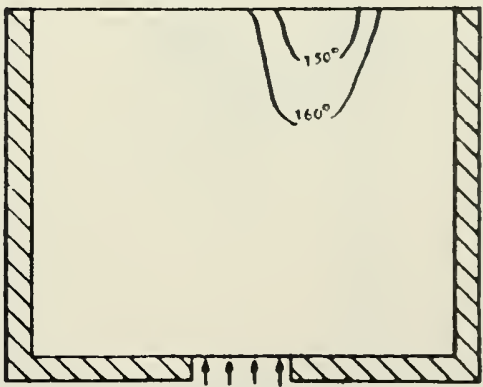

Air

After $81 / 2$ Hours of Air Flow

Figure 19-A. Drying Isotherms At Selected Time Intervals Bales Oriented "Flat". 


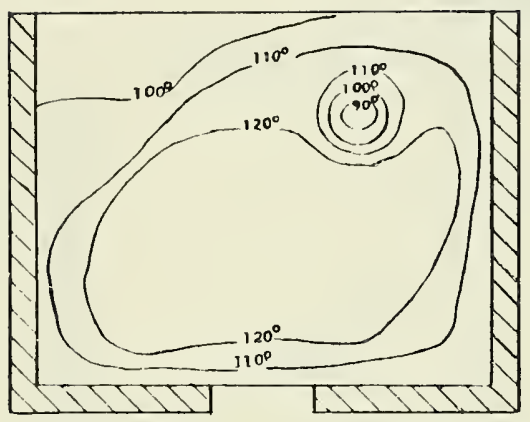

After 8 Hours Spont aneous Heating

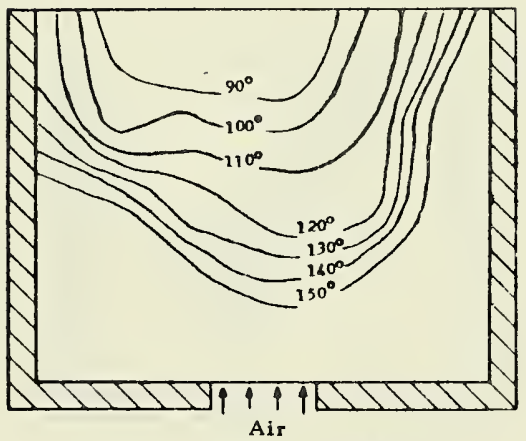

After 2 Hours of Air Flow

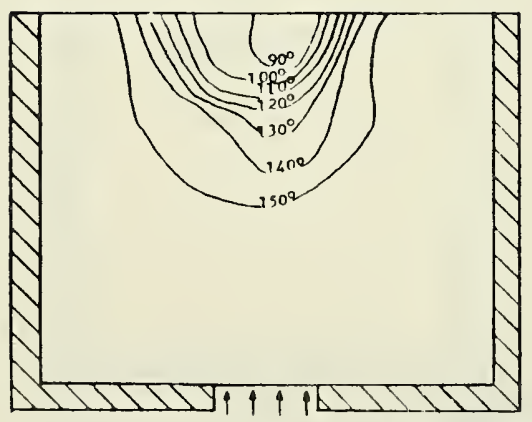

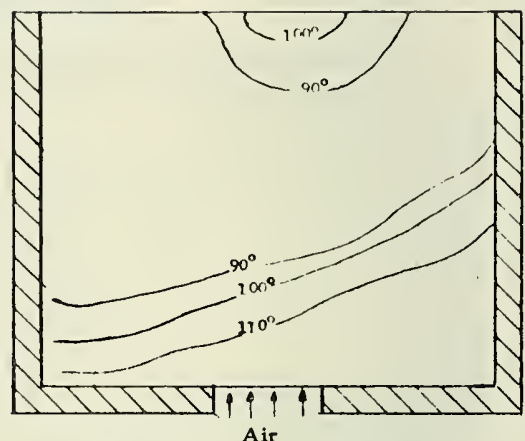

After $1 / 2$ Hour of Air Flow

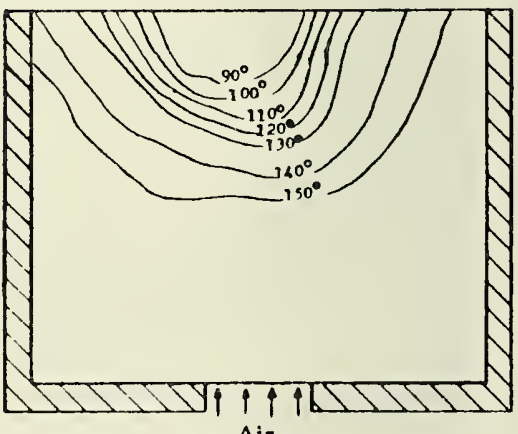

After 4 Hours of A ir Flow

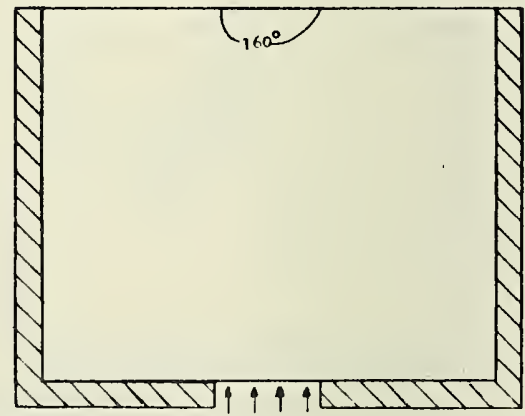

\section{Air}

Air Flow $-85 \mathrm{cfm} / \mathrm{ft}^{2}$

Air Temperature-1600F. After 12 Hours of Air Flow

Relative Humidity $-10 \%$

Per cent Moisture-50\%
Pert 10.2 lbs $/ \mathrm{ft}^{3}$

Figure 19-B. Drying Isothermss At Selected Tíme Intervals Bales Oriented "Flat". 


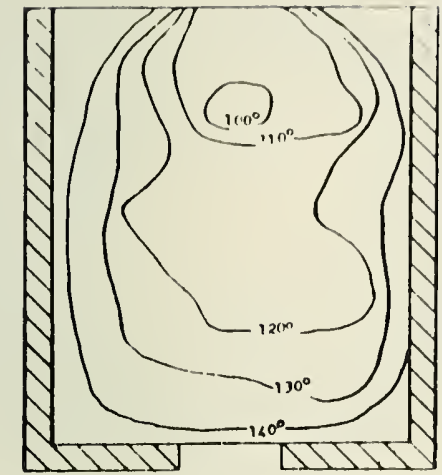

After 4 Hours of Spontaneous Heat ing

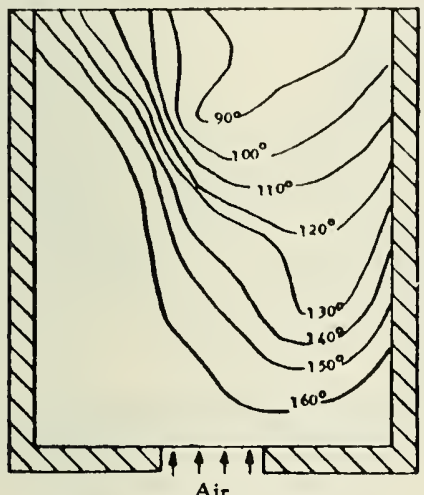

After 2 Hours of Air Flow

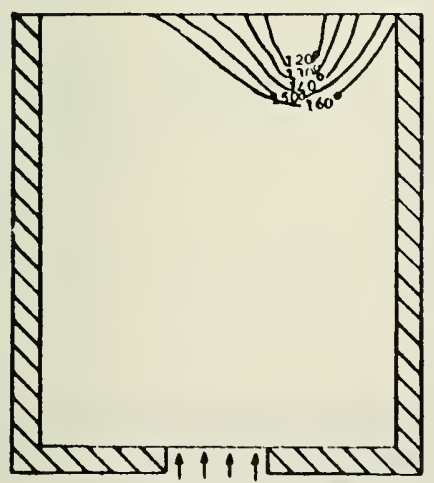

Air

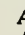

Air Flow- $130 \mathrm{cfm} / \mathrm{ft}^{2}$

A $A$

Relative Humidity- $-9 \%$

Density -6.9 ibs $/ \mathrm{ft}^{3}$

Density -6.9 lbs $/ \mathrm{ft}^{3}$
Per cent Moisture $48 \%$

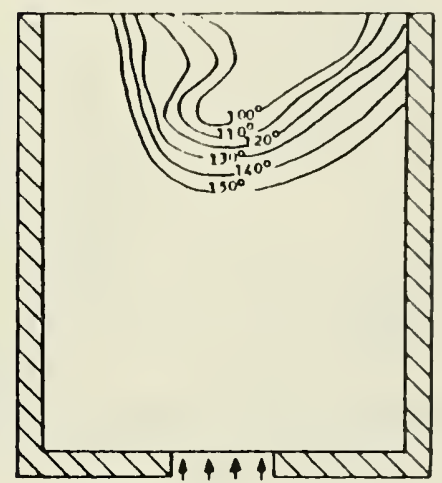

After 4 Hours of Air Flow

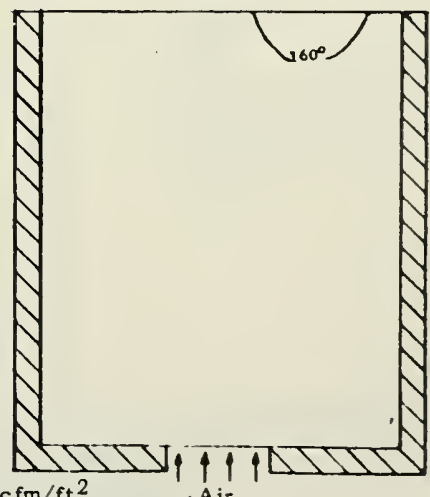

After 6 Hours of Air Flow fter 5 Hours of Air Flow

Figure 19-C. Drying Isotherms at Selected Time Intervals Bales Oriented "On Edge". 


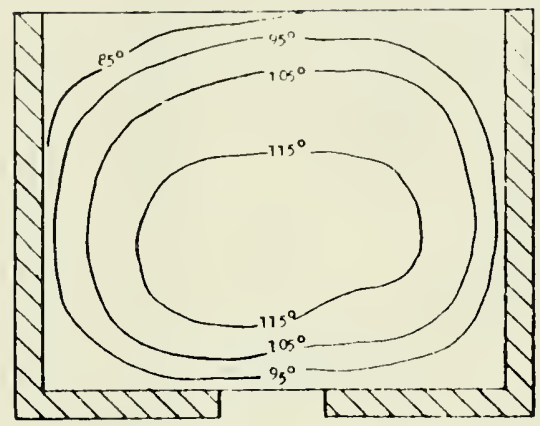

After 6 Hours Spontaneous Heating

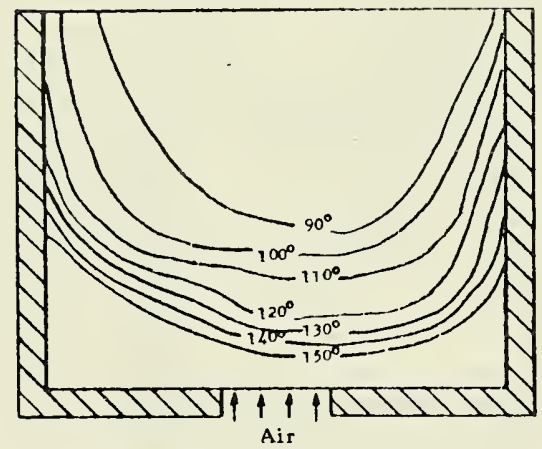

After 2 Hours of Air Flow

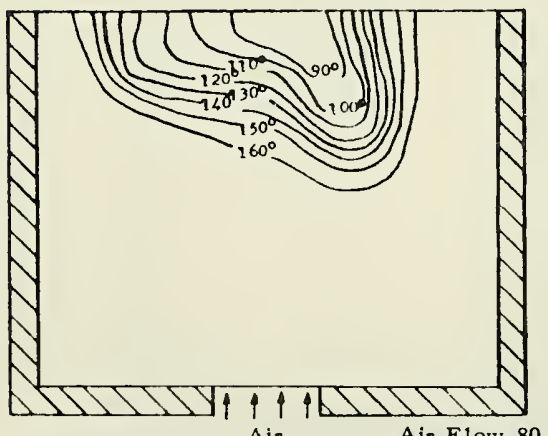

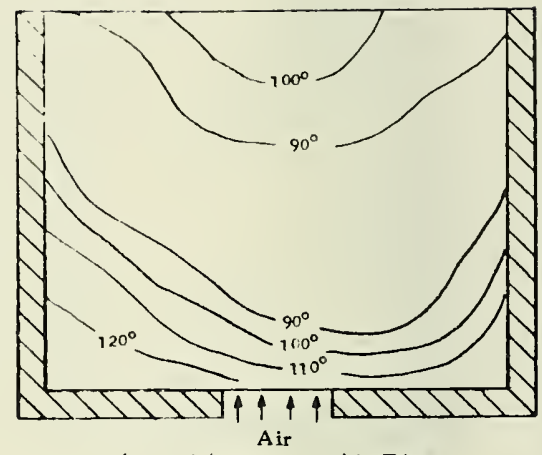

After $1 / 2$ Hour of Air Flow

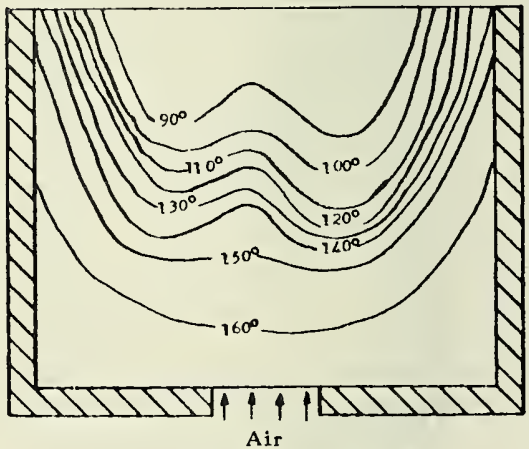

After 5 Hours of Air Flow

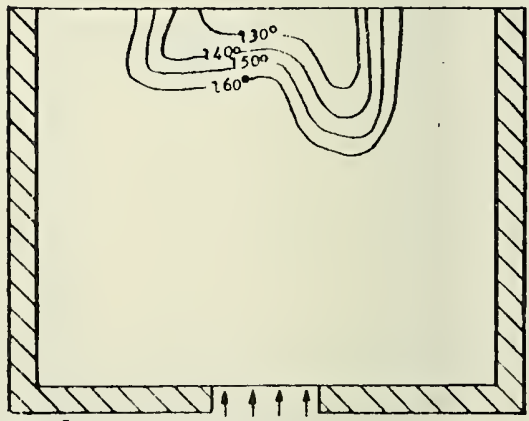

After 11 Hours of Air Flow Air Temperature- $160^{\circ} \mathrm{F}$. After 16 Hours of Air Flow Relative Humidity $-8 \%$

Density- 13.7 bs $\mathrm{ft}^{3}$

Per cent Moisture-33\%

Figure 19-D. Drying Isotherms At Selected Time Intervals Bales Oriented "Flat". 

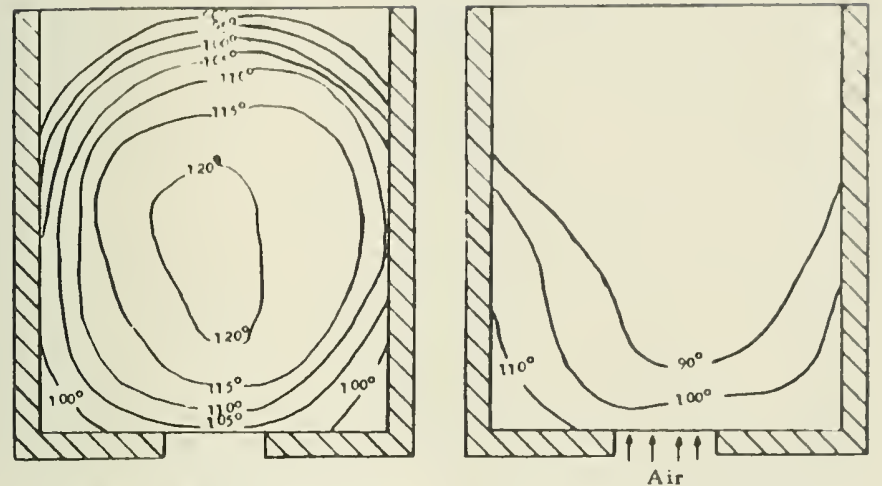

After 6 Hours Spontaneous Heating

After $1 / 2$ Hour of Air Flow

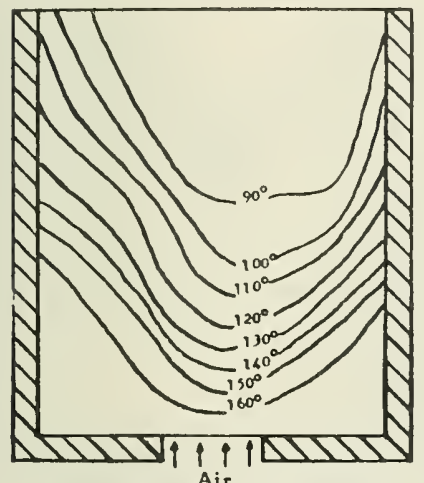

After 2 Hours of Air Flow

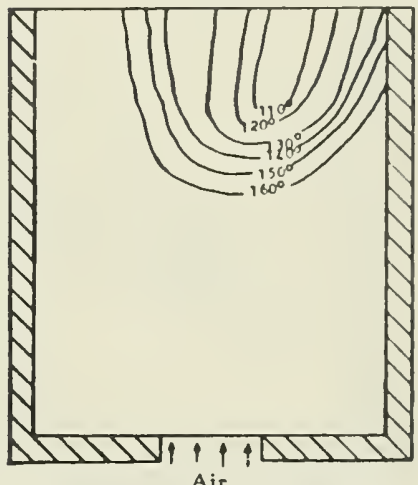

After 5 Hours of Air Flow
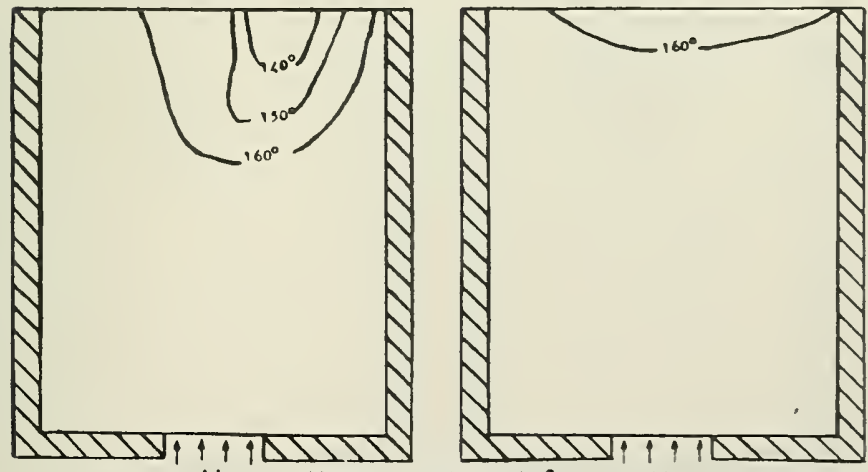

Air

Air F10w-120 cfm/ft 2

Air

After 6 Hours of Air Flow Air Temperature-160\% F. After 7 Hours of Air Flow Relative Humidity- $8 \%$

Density- $11.8 \mathrm{lbs} / \mathrm{ft}^{3}$

Per cent Moi sture-33\%

Figure 19-E. Drying Isorherms At Selected Time Intervals Bales Oriented "On Edge". 


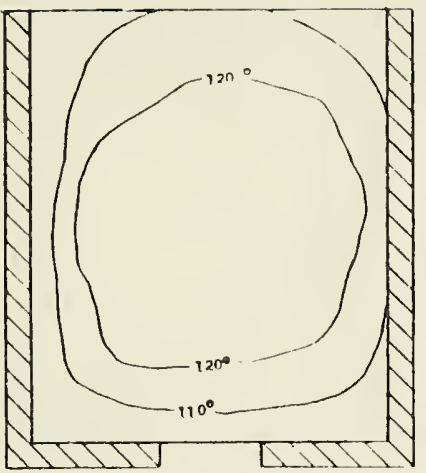

After 8 Hours Spontaneous Heating

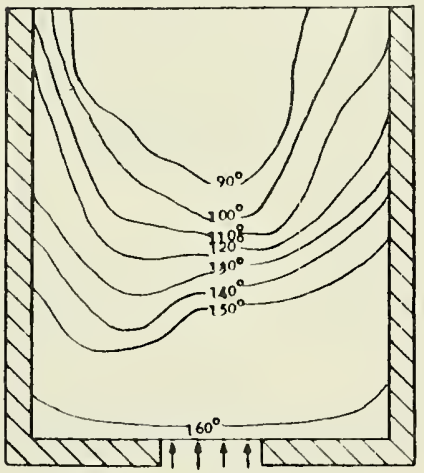

Air

After 2 Hours of Air Flow

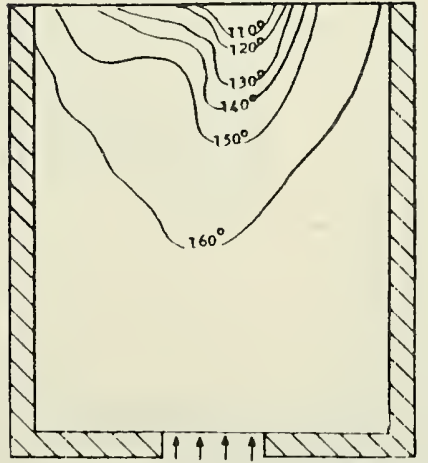

Air F1ow-130 cfm/ft 2

Air

After 6 Hours of Air Flow

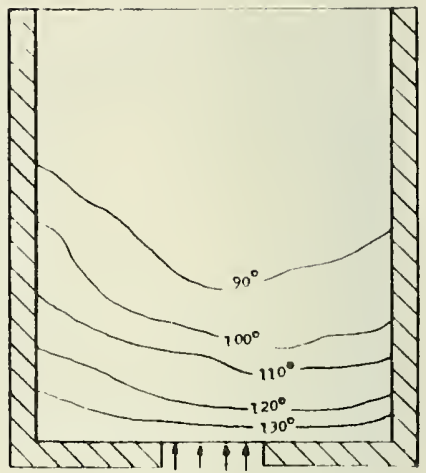

Air

After $1 / 2$ Hour of Air Flow

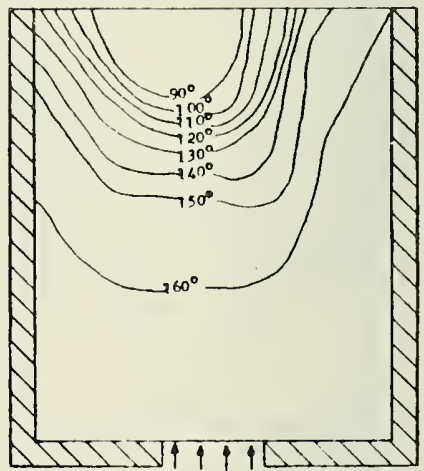

Air

After 4 Hours of Air Flow

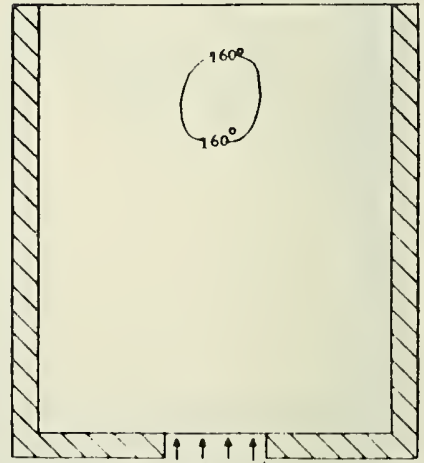

Air

After 8 Hours of Air Flow Relative Humidity-10\%

Density $\mathbf{- 8 . 8} \mathrm{lbs} / \mathrm{ft}^{3}$

Per cent Moisture- $50 \%$

Figure 19-F. Drying Isotherms At Selected I ine Intervals Bales Oriented "On Edge". 


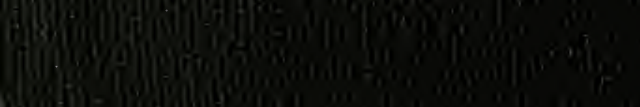

in:

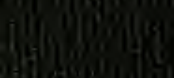

aty

for

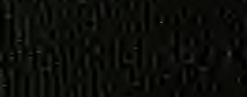

iflos

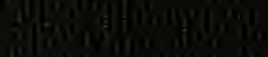

?:

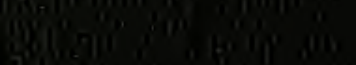

$\lim ^{101}$

(1) 